\title{
Semi-natural habitats support biological control, pollination and soil conservation in Europe. A review
}

\author{
John M. Holland ${ }^{1}$ (D) - Jacob C. Douma ${ }^{2,3} \cdot$ Liam Crowley $^{1} \cdot$ Laura James $^{1} \cdot$ Laura Kor $^{1}$ • \\ David R.W. Stevenson ${ }^{1}$ • Barbara M. Smith ${ }^{1,4}$
}

Accepted: 8 June 2017 / Published online: 24 July 2017

(C) INRA and Springer-Verlag France SAS 2017

\begin{abstract}
Semi-natural habitats are integral to most agricultural areas and have the potential to support ecosystem services, especially biological control and pollination by supplying resources for the invertebrates providing these services and for soil conservation by preventing erosion and run-off. Some habitats are supported through agri-environment scheme funding in the European Union, but their value for ecosystem service delivery has been questioned. An improved understanding of previous research approaches and outcomes will contribute to the development of more sustainable farming systems, improve experimental designs and highlight knowledge gaps especially for funders and researchers. Here we compiled a systematic map to allow for the first time a review of the quantity of evidence collected in Europe that semi-natural habitats support biological control, pollination and soil conservation. A literature search selected 2252 publications, and, following review, 270 met the inclusion criteria and were entered into the database. Most publications were of pest control (143 publications) with less on pollination (78 publications) or soil-related aspects (31). For pest control and pollination, most publications reported a positive effect
\end{abstract}

John M. Holland

jholland@gwct.org.uk

1 Game and Wildlife Conservation Trust, Fordingbridge, Hampshire SP6 1EF, UK

2 Centre for Crop System Analysis, Wageningen University, Droevendaalsesteeg 1, 6708PB Wageningen, The Netherlands

3 Laboratory of Entomology, Wageningen University, Droevendaalsesteeg 1, 6708PB Wageningen, The Netherlands

4 Present address: Centre for Agroecology, Water and Resilience, Coventry University, Ryton Gardens, Wolston Lane, Coventry, Warwickshire CV8 3LG, UK of semi-natural habitats. There were weaknesses in the evidence base though because of bias in study location and the crops, whilst metrics (e.g. yield) valued by end users were seldom measured. Hedgerows, woodland and grassland were the most heavily investigated semi-natural habitats, and the wider landscape composition was often considered. Study designs varied considerably yet only $24 \%$ included controls or involved manipulation of semi-natural habitats. Service providers were commonly measured and used as a surrogate for ecosystem service delivery. Key messages for policymakers and funders are that they should encourage research that includes more metrics required by end users, be prepared to fund longer-term studies ( $61 \%$ were of only 1 -year duration) and investigate the role of soils within semi-natural habitats in delivering ecosystem services.

Keywords Agroecology · Ecosystem services · Agricultural policy $\cdot$ Pollinators $\cdot$ Sustainable agriculture $\cdot$ Integrated pest management $\cdot$ Experimental design $\cdot$ Agricultural research

\section{Contents}

1. Introduction

2. Method

3. Results

3.1 The extent to which the ecosystem services (biocontrol, pollination, soil conservation) in relation to semi-natural habitats been investigated across Europe

3.1.1 Geographic variation of publications

3.2 The types of semi-natural habitats that have been investigated and impact for a range of crops

3.3 Other factors effecting ecosystem service delivery

3.4 Study setup, sampling methodology, sampled locations and farming systems 
3.5 Studies of pest control

3.6 Studies of pollination

3.7 Approaches for investigating service providers

3.8 Outcomes for ecosystem service delivery

4. Conclusions

4.1 Extending the geographic extent of ecosystem services research across Europe

4.2 Ways of improving ecosystem service delivery

4.3 Filling the gaps

4.3.1 Crops

4.3.2 Interactions between ecosystem services

4.3.3 Yield

4.3.4 Pollination

4.3.5 Seldom investigated ecosystem services

4.4 Recommendations for improving ecosystem services delivery

4.5 Recommendations / notes for policy makers

Acknowledgements

References

References of the systematic map

\section{Introduction}

Throughout the European Union, member states are implementing agri-environment schemes through the Common Agricultural Policy that protect or create seminatural habitats, here defined as "any habitat within or outside of the crop containing a community of non-crop plant species". Agri-environment schemes typically have multiple objectives that include nature conservation and resource protection (e.g. water quality), yet despite their considerable cost, their benefits have been questioned. This has been highlighted most with respect to conservation, because the target species have not always shown the expected response (Kleijn et al. 2006). However, semi-natural habitats have the potential to support ecosystem services and, since the Millennium Ecosystem Assessment (MA2005), there has been increasing interest in investigating and quantifying these services in agricultural systems (e.g. Vihervaara et al. 2010; van Zanten et al. 2014). In addition, EU member states are obliged to adopt Integrated Pest Management principles as of 2014 under the Sustainable Use Directive (2009/128/ EC) and semi-natural habitats can contribute towards this through enhancement of biological control. The other important ecosystem services provided or supported by seminatural habitats are pollination and soil conservation (Wratten et al. 2012). Semi-natural habitats provide habitats and resources for the agents delivering biological control and pollination. These resources include shelter for aestivation or overwintering, breeding sites, food resources and an appropriate environment protected from agricultural operations (Landis et al. 2000; Holland et al. 2016). Semi-natural habitats themselves can sequester carbon within both vegetation and soil (Walter et al. 2003), whilst the vegetation's physical structure can also hinder soil loss through erosion (Lowrance et al. 2002).

The role that semi-natural habitats play in providing ecosystem services has been widely investigated using a range of empirical approaches across the European Union. The types of investigation vary from evaluations of individual habitats (Holland et al. 2016) to landscape scale studies (e.g. Thies and Tscharntke 1999). How such studies were conducted varied considerably. For pollination, a relatively straightforward ecosystem service to measure, 62 unique metrics were used in 121 publications (Liss et al. 2013). Such variation makes comparisons difficult between publications and can lead to discrepancies in the interpretation of findings and recommendations (Liss et al. 2013). A similar review of the approaches used to investigate other ecosystem services is not readily available. Yet, ensuring consistent methodologies are used could ensure that there is no bias in emphasis for policy and may make it possible to assess trade-offs between ecosystem services (Fig. 1).

Knowing which approaches have been used previously and their sensitivity to measuring ecosystem services has a number of advantages: (1) it can help ensure standardised ones are used in future research, (2) reviewing the success of previous publications across Europe can help identify which seminatural habitats and cropping systems have already been investigated allowing users to identify research from countries with similar ecological infrastructure and cropping, (3) it can help to highlight knowledge gaps and identify topics for indepth meta-analysis and (4) such reviews can help determine the most appropriate metrics, scale and experimental design on which to base further investigations and can help researchers and funding bodies to better target their research strategy.

If semi-natural habitats are to be managed optimally to improve ecosystem services provision on farmland across Europe thereby helping justify the public money invested in it through the Common Agricultural Policy, then it is important to understand the current state of knowledge. The main objective in this study was to summarise the quantity of evidence that has been collected in Europe on semi-natural habitats with respect to the key ecosystem services that seminatural habitats support, namely biological control, pollination and soil conservation. The secondary objectives were to synthesise this knowledge for use by other researchers, funders and end-users, and to provide a map on this topic that is searchable. Specifically, we asked the following:

1. To what extent have these ecosystem services (biocontrol, pollination, soil conservation) in relation to semi-natural habitats been investigated across Europe's agricultural production areas? 
Fig. 1 Grass strip between fields with pan traps for collecting pollinators and example of a flower-rich margin

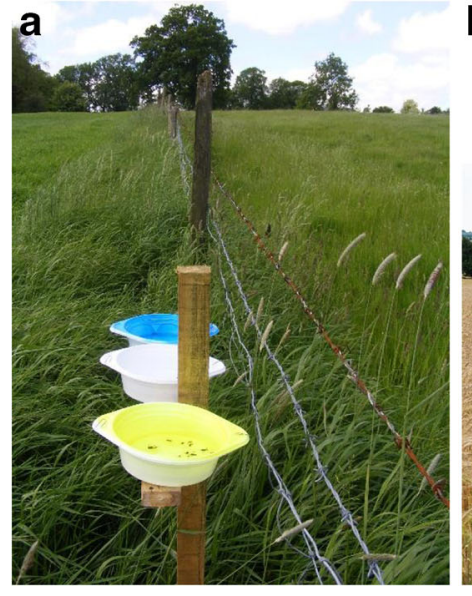

b

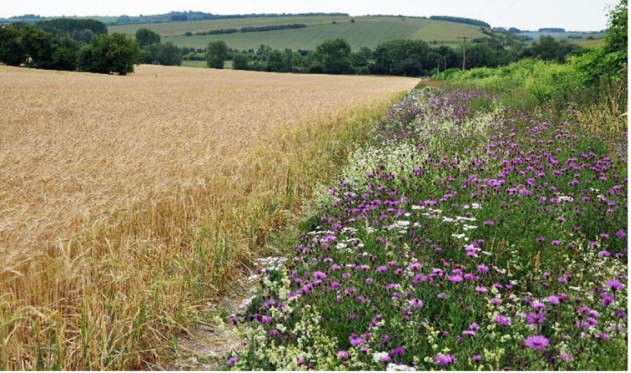

2. Which semi-natural habitat types have been investigated and for which ecosystem services?

3. What methodologies were used and how did this influence the outcomes?

4. What were the outcomes for ecosystem services delivery?

The outcomes can (1) provide researchers and funding bodies with summary information that will support them in targeting research, (2) enable policymakers to consider the strength of evidence currently available to underpin decision-making, (3) help them identify priorities for research scoping (4) identify consistent benefits that can be utilised in the development of more sustainable farming systems.

\section{Method}

A systematic map approach was chosen as the appropriate method for this review as it allowed the identification and categorisation of available evidence to form a searchable database (Grant and Booth 2009). Systematic maps are methodical overviews of the quantity and quality of evidence in relation to a broad (open) question of policy or management relevance. They help to understand the breadth and depth of the evidence available. The process and rigour of the mapping exercise is the same as for systematic review except that they make no attempt to answer a specific question but instead collate all the evidence available on a topic of interest (James et al. 2016). However, the systematic map still allows areas to be identified where there is sufficient evidence for meta-analysis. In addition, it allows the identification of gaps for future research. Systematic maps include all the publications that meet a set of a priori inclusion rules set by the authors thereby effectively summarising the relevant literature. Guidance on the compilation of systematic maps has been published (James et al. 2016) and is available online
( http: / / www.environmentalevidence.org/ Instructionsforauthors_maps.html [27/04/2016].

The types of semi-natural habitat that occur and are supported by agri-environment schemes across Europe vary considerably (Keenleyside et al. 2011), although there are some broad categories. Of the 63 types of entry-level options classified from the EU-27 Rural Development Plans, 15 broader categories were identified some of which are semi-natural habitats (grassland, cover in permanent crops, buffer strips, management for wildlife and land taken out of production), but the list does not encompass all semi-natural habitats commonly occurring on farmland (e.g. woodland, hedgerows) and there are some semi-natural habitats designed specifically for ecosystem services such as pollination (flower-rich areas) and biological control (beetle banks). In addition, semi-natural habitats may also occur within fields such as the cover under perennial crops or established to prevent soil erosion. The final list selected for investigation therefore included some additional semi-natural habitat types (see search terms below).

A literature search was conducted that was comprehensive and precise enough to find as much of the relevant literature as is realistically possible whilst avoiding the capture of too much irrelevant literature. Only peer-reviewed, published papers describing empirical, original research was included (reviews, meta-analyses and landscape modelling were excluded), and searches were carried out using the online database: Web of Knowledge (v.5.10) for the period 1950-2015 (November). A scoping process that included review by the partners of the QuESSA project was used to refine and select the final search terms (Holland et al. 2014). Searches were only conducted in the English language, and a wildcard $(*)$ was used to select multiple word endings or plurals. The final search term was ((woodland OR "field margin" OR "grass margin" OR hedge* OR "unimproved grass*" OR "field boundary" OR "cover crop" OR fallow OR "semi-natural grass*" OR landscape*) AND ("ecosystem service*" OR pollinat* OR "pest control" OR biocontrol OR "biological 
control" OR "seed predation" OR "soil erosion" OR "soil organic matter") AND (agricultur* OR farm*)). The search was restricted to research conducted in Europe by adding 31 European countries to the address option (see Appendix). All results from the search results were reviewed at title and abstract level to ensure they met a set of inclusion criteria as follows:

1. European: the study must have been entirely carried out in a European country.

2. Agricultural interest: it must not only have a conservation concern, but must also be relevant to farming systems.

3. Semi-natural habitat OR Landscape complexity: the effects of semi-natural habitats OR landscape complexity must be investigated in the study.

4. Invertebrates OR Other service provider: the organisms providing an ecosystem service must be invertebrates OR an ecosystem service must be influenced by seminatural habitats or landscape complexities (e.g. use of semi-natural habitats to prevent soil erosion).

5. Empirical study: the article must report the results of a primary empirical study. Correlative and manipulative studies are included, but literature reviews and statistical models are not.

6. Natural populations: papers investigating the effect of introduced pest enemies were not included, but enhancement of existing populations was acceptable.

Following initial scoping exercises to test search terms and responses, two reviewers divided the workload to determine whether the papers met inclusion criteria. A search was conducted in October 2014. Quality was controlled through reciprocal sub-sampling between assessors. If one or more of these criteria were not met, the paper was not included in the final systematic map. Articles that passed the inclusion criteria were then read in full, and entered into the database by extraction of the relevant data (Table 1). The search was then repeated in November 2015 adding in the term for landscape, and the whole process was repeated, adding any additional literature, which provided a further check on the original search.

\section{Results}

The search terms returned 2252 publications, and these were reviewed for suitability for inclusion; of these, 270 met the inclusion criteria and were entered into the systematic map database. The number of publications investigating the selected ecosystem services covered by the systematic map rose steadily over the last 10 years reaching approximately 30 per year by 2014 (Fig. 2).
3.1 The extent to which the ecosystem services (biocontrol, pollination, soil conservation) in relation to semi-natural habitats have been investigated across Europe

The majority of publications looked at regulating ecosystem services (250), whilst 28 investigated supporting services, 12 measured provisioning and three measured cultural services. The most commonly investigated regulating ecosystem services were pest control $(55 \%)$ and pollination (30\%), with the other ecosystems services having 20 (7\%) or less publications (Fig. 3). Thirty-one publications investigated soil-related ecosystem services such as soil resilience and carbon sequestration. Of supporting services, 26 investigated nutrient cycling or levels of soil organic matter and one publication each on seed dispersal and soil formation. Twenty-three publications investigated two or more ecosystem services, these most often being pest control and pollination.

\subsubsection{Geographic variation of publications}

Publications originated from 23 countries, but there was geographic bias because most were conducted in 9 countries that had $>10$ publications. The highest number of publications originated from Germany (64), followed by France, Spain, Sweden and the UK (21-26) (Fig. 4). Only nine publications reported on studies conducted in more than one country. Pest control was the most widely researched ecosystem services, investigated in all but three countries. Pollination was most heavily investigated in Germany, Sweden and UK with each 10 or more publications. Few publications on other ecosystem services were included in the database.

\subsection{The types of semi-natural habitats that have been investigated and impact for a range of crops}

A total of 245 publications specifically investigated a type of semi-natural habitat of which half (137 publications) investigated more than one habitat type. Thirty-one percent of these publications included hedgerows/field margins, $23 \%$ woodland or shrubland and $28 \%$ grassland (Fig. 5). Investigations of fallows were reported in $8 \%$ of publications whilst the other habitats were addressed by only $12(2 \%)$ or fewer publications. In these publications, the locations where service providers or ecosystem services were most commonly measured were hedgerows or field margins (44\%), woodland/shrubland (19\%) and grassland (25\%) (Fig. 6). Only areas within fields, orchards, olive groves or vineyards were sampled in 106 publications.

Of the 230 publications that looked at ecosystem services within crops, the most studied were wheat $(25 \%)$ and oilseed rape (15\%), followed by barley ( $9 \%$ ) and other cereals such as triticale, rye, spelt and oats (9\%) (Fig. 7). Perennial, vegetable and root crops were relatively poorly investigated. 
Table 1 Fields used to code publications in the database
ID

Identification code (in bold) assigned by WoK during search or descriptive text was used

$\begin{array}{ll}\text { First author } & \text { Surname, initial of first author } \\ \text { Title } & \text { Full article title } \\ \text { Year } & \text { Four-digit year of publication } \\ \text { Reference } & \text { Full reference of article (Harvard) } \\ \text { Ref. type } & \text { Journal } \\ & \text { What type of source did the entry come from } \\ \text { Text read } & \text { Full text }\end{array}$

How much of the text was read by review author when entering

Linked studies

Coded

Intervention

English

Countries

Length of study in years

Study type

Control

Randomised

Spatial replicate

Temporal replicate

Study Scale

Time of year of measurements

Farm system

Sampling Location

Reason heterogeneity results

Semi-natural habitat types

ES provided by invertebrates?

Providers

Sampling method for predation

Provider Sampling Location

Sampling for provider resources

ES Type

ES measured: Provisioning
ID codes of all other entries in review that are linked by the same first author and/or the same study

YES Has the article been coded into review

What is the independent variable

$\mathbf{Y} / \mathbf{N}$ Is the language of the article English

Which country/countries was the study conducted in

How long, in full years, did the study take place for

Manipulative/correlative

Was the study manipulative or correlative

$\mathbf{Y} / \mathbf{N}$ Was there a control

Y/N Was randomisation incorporated into the study design

$\mathbf{Y} / \mathbf{N}$ Was there a spatial replicate

$\mathbf{Y} / \mathbf{N}$ Was there a temporal replicate

\section{Farm/multi-farm}

Was the study restricted to one farm or did it incorporate multiple farms Which season(s) was the study conducted in

\section{Arable/orchard/livestock}

What type of farming system was being used

In what specific location(s) within the farm was the study conducted

Reasons that led to any heterogeneity in results

What types of semi-natural habitats were involved in the study

$\mathbf{Y} / \mathbf{N}$

Is the ES being provided done so via invertebrates, or from other source (e.g. semi-natural habitats improving soil quality in adjacent fields)

Only applicable when ES is provided by invertebrates

Pest natural enemies/pollinators/nutrient cycling

What type of ES were the arthropods providing

Only applicable when ES is provided by invertebrates

What method was used to sample the providers

Only applicable when ES is provided by invertebrates

Crop/semi-natural habitats

Which location were the providers sampled from

Only applicable when ES is provided by invertebrates

What sampling (if any) for provider resources was conducted

Regulating/provisioning/cultural/supporting

What type of ES is being provided

Only applicable when ES type $=$ Provisioning

Food/water/energy/pharmaceuticals/minerals

What type of provision is being examined 
Table 1 (continued)

ID

ES measured: Regulating

ES measured: Cultural

ES measured: Supporting

ES methodology

Effect on yield

$\%$ change in yield

Type of semi-natural habitats effecting yield

Effect on Pest Control

$\%$ change in pests

Type of semi-natural habitats effecting pest control

Effect on Pollination

$\%$ change in pollination

Type of semi-natural habitats effecting pollination

Effect on seed predation

$\%$ change in seed predation

Type of semi-natural habitats effecting seed predation

Effect on soil Erosion

$\%$ change in soil erosion

Type of semi-natural habitats effecting soil erosion

Effect on SOM

Type of semi-natural habitats effecting SOM

Extracting data

Organism investigated

Notes
Identification code (in bold) assigned by WoK during search or descriptive text was used

Only applicable when ES type = Regulating

Pollination/pest control/carbon sequestration/soil resilience/water purification/waste decomposition

What type of regulation is being examined

Only applicable when ES type = Cultural

Cultural inspiration/recreational experience/scientific discovery

What type of cultural ES is being examined

Only applicable when ES type = Supporting

Nutrient cycling/seed dispersal/soil formation/primary production

What type of supporting ES is being examined

What was measured in order to quantify ES provided

Positive/negative/no effect/not measured

What effect of the intervention on the yield

The $\%$ increase or decrease in yield that was found

The type semi-natural habitats with the greatest impact on yield

Positive/negative/no effect/not measured

What effect did the intervention have on the level of pest control

The $\%$ increase or decrease upon the level of pest control

The type of semi-natural habitats with the greatest effect on pest control

\section{Positive/negative/no effect/not measured}

What effect did the intervention have pollination

The $\%$ increase or decrease upon the level of pollination

The type of semi-natural habitats with the greatest effect on pollination

\section{Positive/negative/no effect/not measured}

What effect did the intervention have on the level of seed predation

The $\%$ increase or decrease upon the level of seed predation

The type of semi-natural habitats with the greatest effect on seed predation

\section{Positive/negative/no effect/not measured}

What effect did the intervention have on the level of pest control

The $\%$ increase or decrease upon the level of soil erosion

The type of semi-natural habitats with the greatest effect on soil erosion

\section{Positive/negative/no effect/not measured}

What effect did the intervention have on the level of SOM

The type of semi-natural habitats with the greatest effect on SOM

\section{Easy/moderate/difficult}

What level of difficulty was experienced in extracting data from the publication

Which organism(s) where the subject of the study

Any additional relevant notes about the entry

\subsection{Other factors effecting ecosystem service delivery}

A high proportion of publications (43\%) investigated whether the composition of the surrounding landscape affected the selected ecosystem services. These publications were used for example the proportion of arable land, uncropped land or specific habitats to provide an indication of the landscape complexity. Some other factors that may also affect these 
ecosystem services were also investigated. These included 41 publications in which farming systems such as conventional and organic or those with different levels of inputs were examined. There were 30 publications in which the type of ground management, fertiliser inputs, grazing intensity or seed mix was investigated and 18 publications of cover crops. Only two publications examined grazing management.

\subsection{Study setup, sampling methodology, sampled locations and farming systems}

The experimental design used in each study was extracted. Excluding 12 publications in which long-term data ( $>8$ years) was analysed, 64\% were single-year studies, $18 \%$ of 2-year duration and $13 \%$ of 3-8-year duration. The most common design was one using a non-randomised, correlative approach without a control (34\%), whilst a further $20 \%$ used the same design but with a randomised approach. To show effects on the selected ecosystem services, the correlative studies usually employed some quality or quantity of semi-natural habitats rather than formal randomised designs with experimental manipulations of semi-natural habitat type or area. Overall, only $24 \%$ of all publications included any type of control treatment. The majority of publications included spatial or temporal replication (Fig. 8). In manipulative studies that tested interventions through experimental manipulations to create treatments, more studies did not use controls (59 publications) than those that did (44); however, randomisation was more commonly employed when there was a control. The most robust experimental approach using manipulation, randomisation and controls was only used in $11 \%$ of publications. It was not possible to identify whether the type of experimental design determined the final recommendations because, where an effect was reported, most were positive regardless of the approach or ecosystem service (pest control $83 \%$, pollination $79 \%$ ).

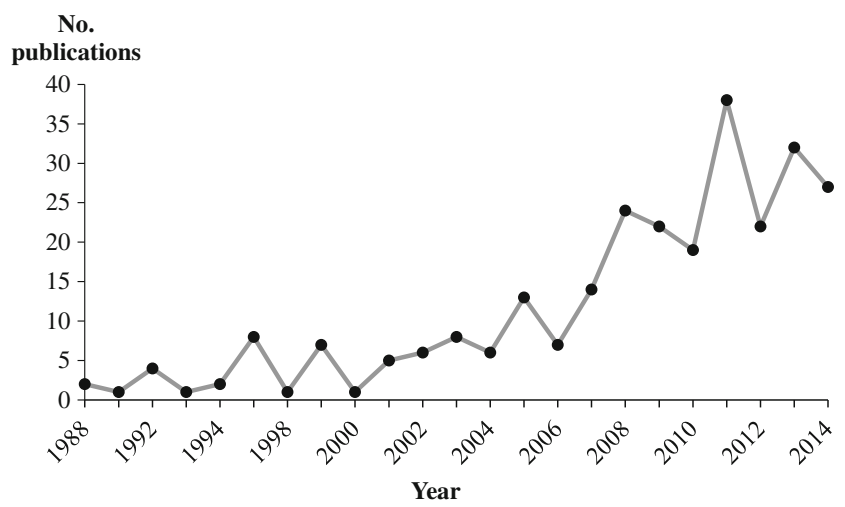

Fig. 2 The number of publications in the systematic map per annum $(n=270)$

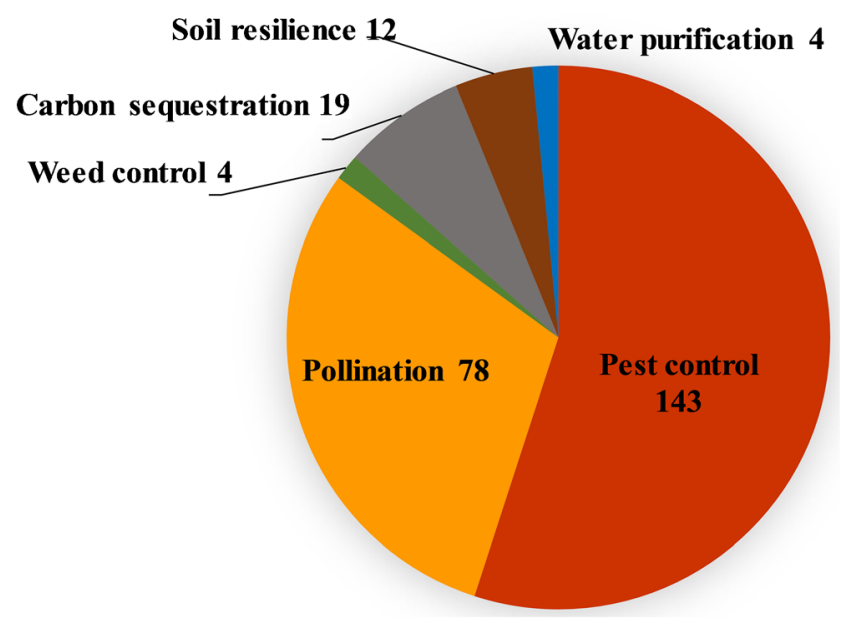

Fig. 3 The number of publications for each regulating ecosystem service $(n=260)$

Overall, $73 \%$ of publications reported on studies conducted on more than one farm (site), whilst the remainder were of a single study site. Most publications originated from studies conducted on arable farms $(81 \%), 12 \%$ were in orchards and $6 \%$ were on livestock farms; these were the most frequently investigated systems regardless of whether pest control or pollination was investigated (Fig. 9).

\subsection{Studies of pest control}

Of the 143 publications that investigated the ecosystem service "pest control", none included measurements of yield. Of these, 138 publications measured the pests, or levels of predators and parasitism. Of these, a remarkably low percentage, $22 \%$, reported on actual pest levels, and only $9 \%$ of these also measured pest predators or parasitism rates $(6 \%)$ or both of these (2\%) (Fig. 10). The majority of the publications on pest control measured predators $(70 \%)$ and fewer parasitism $(25 \%)$.

\subsection{Studies of pollination}

There were 78 publications that investigated pollinators or pollination, and most were conducted in arable crops (Fig. 9). Of these, $87 \%$ measured the number of pollinators; however, only $24 \%$ measured any metric of pollination such as fruit or seed set. The predominant method for assessing pollinators was through transect counts (57\%), pan traps (14\%) (Fig. 11), flower visiting observations (14\%) or netting (10\%).

\subsection{Approaches for investigating service providers}

The most commonly used methods for assessing invertebrates were visual counts of some form either along transect or on the vegetation $(34 \%)$ and pitfall traps $(19 \%)$ which collected 
Fig. 4 The number of publications originating from European countries and the type of ecosystem service investigated

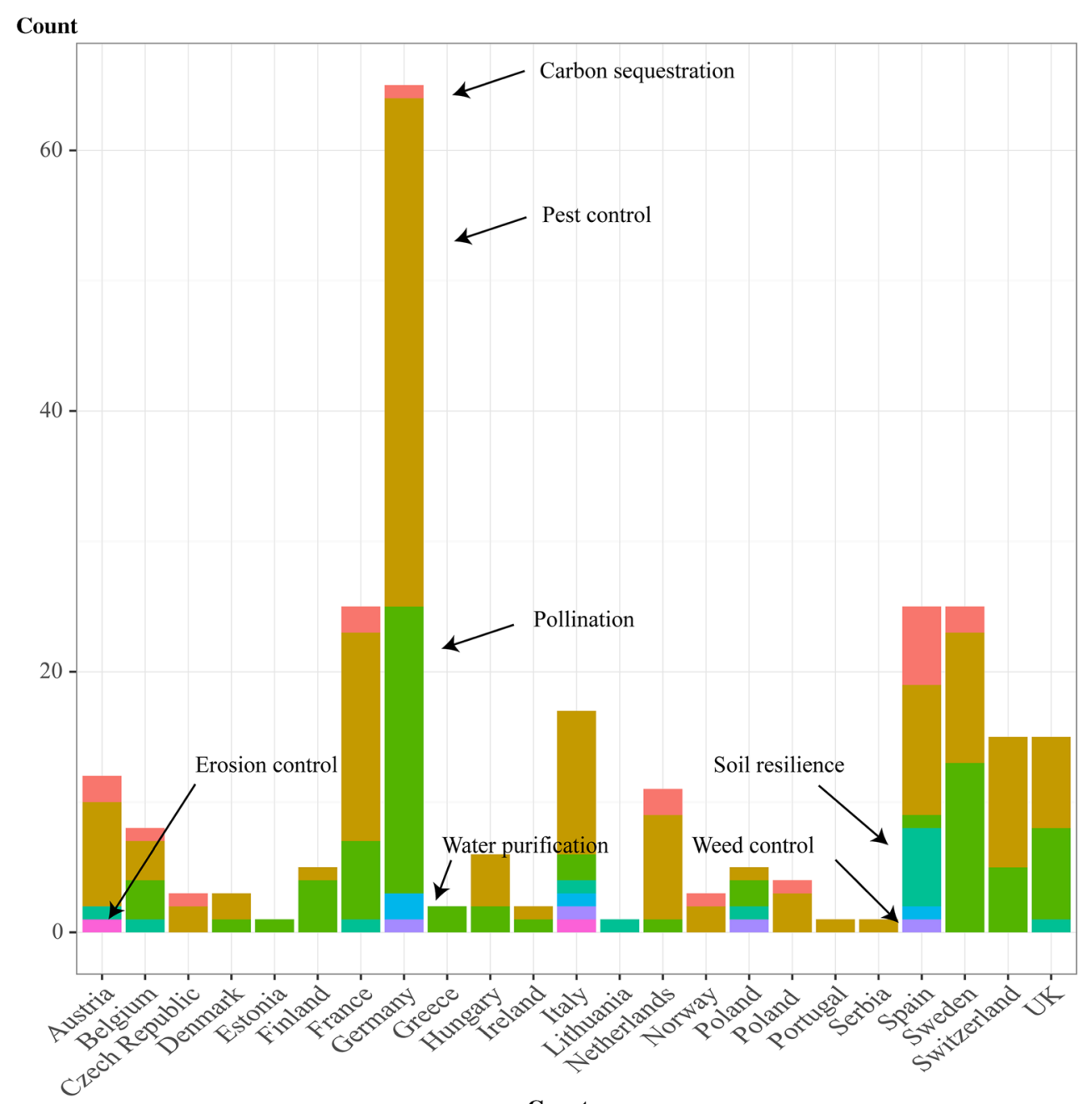

Country epigeal invertebrates (Fig. 11). The transect counts and pan traps were most often used for assessments of pollinators, whilst pitfall traps, suction sampling, sweep nets, window traps and sticky traps were used for collecting predators. Considering all sampling methods, it was more common for either the crop or the semi-natural habitats to be sampled than

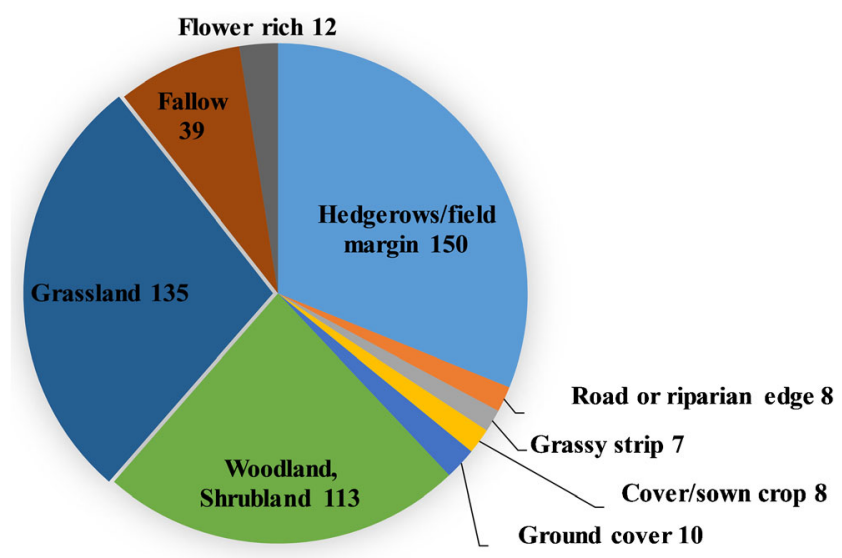

Fig. 5 The number of publications for each type of semi-natural habitat for both, with the exception of sweep netting (Fig. 11). The crop was also more frequently sampled than the semi-natural

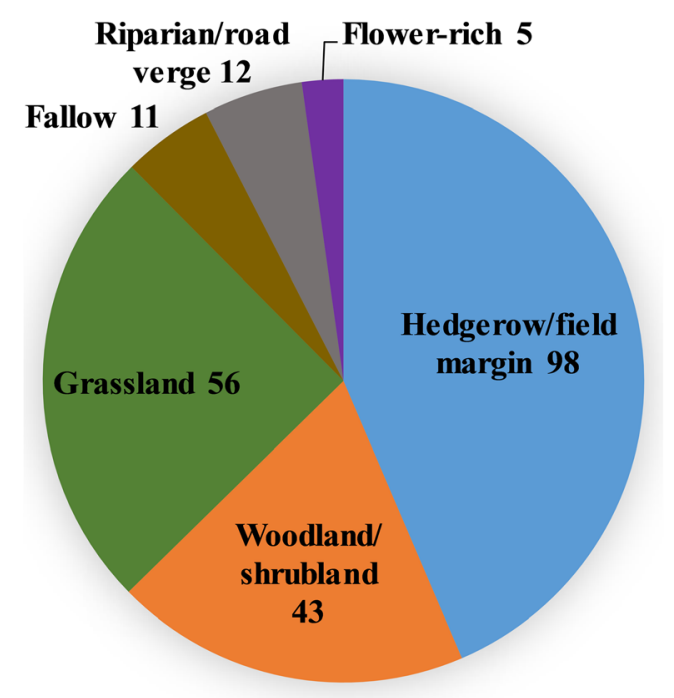

Fig. 6 The number of publications for the semi-natural habitats that were sampled $(n=225)$ 


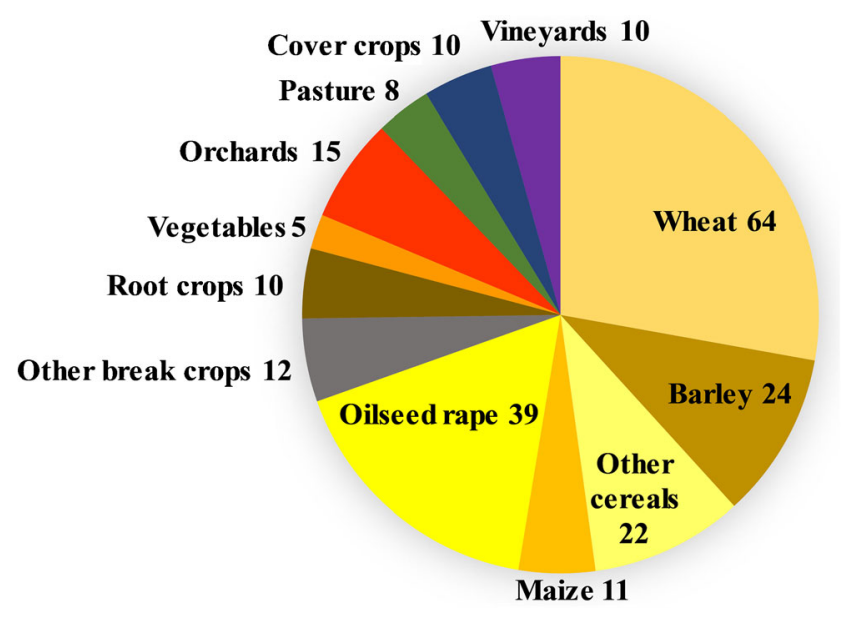

Fig. 7 The number of publications for each crop type habitats for the majority of methods, except where the soil was sampled or when transect counts and water traps were used.

The most extensively studied ecosystem service providers were invertebrates (217) of which $66 \%$ were of pest natural enemies and $36 \%$ of pollinators, although only $1 \%$ of papers covered both groups and there were only two studies of organisms responsible for nutrient recycling. The botanical resources for pest natural enemies and pollinators were less well investigated. Vegetation surveys were conducted in $13 \%$ (35 publications) and 5\% (13 publications) conducted assessments of flower abundance or other measures of floral resources.

Of the invertebrates, Hymenoptera were studied in the most publications (123) because this order includes both bees (pollinators) and parasitic wasps (pest regulators) (Fig. 12). Coleoptera (beetles) were investigated in 37 publications.
Fig. 8 Type of experimental design used to study semi-natural habitats: whether correlative (use of existing landscape elements) or manipulative (habitats created or manipulated), randomised or not, and with or without control treatments
Counts
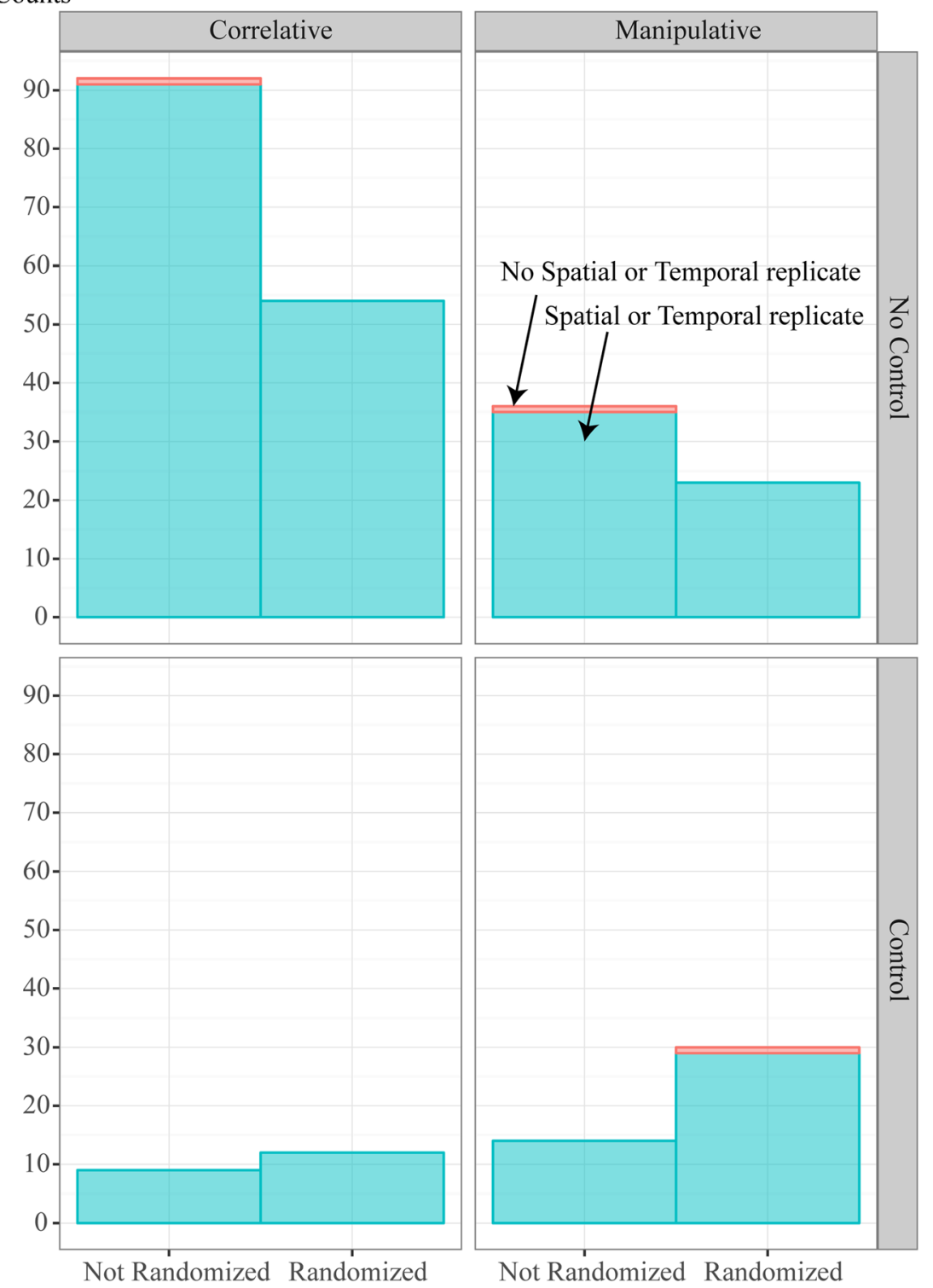
Fig. 9 The effect of semi-natural habitats on pest control and pollination separated by the scale of the study and the cropping system

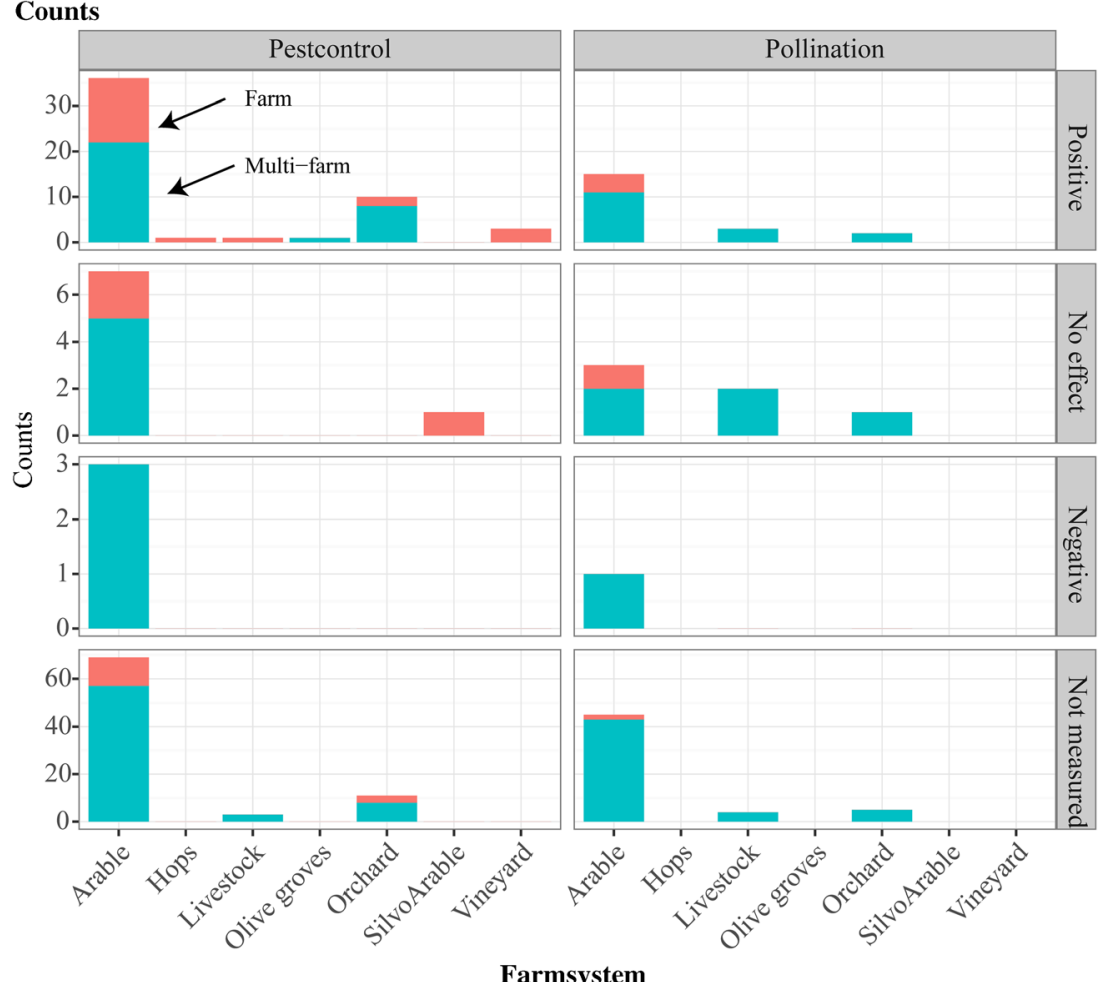

Thirty-two studies were more general in their approach and only assessed functional groups such as predators and aphidophagous predators or total invertebrates.

\subsection{Outcomes for ecosystem service delivery}

Of the $24 \%$ publications that reported an effect of pest control, $81 \%$ of these concluded that there was a positive effect, although of these publications usually the abundance of

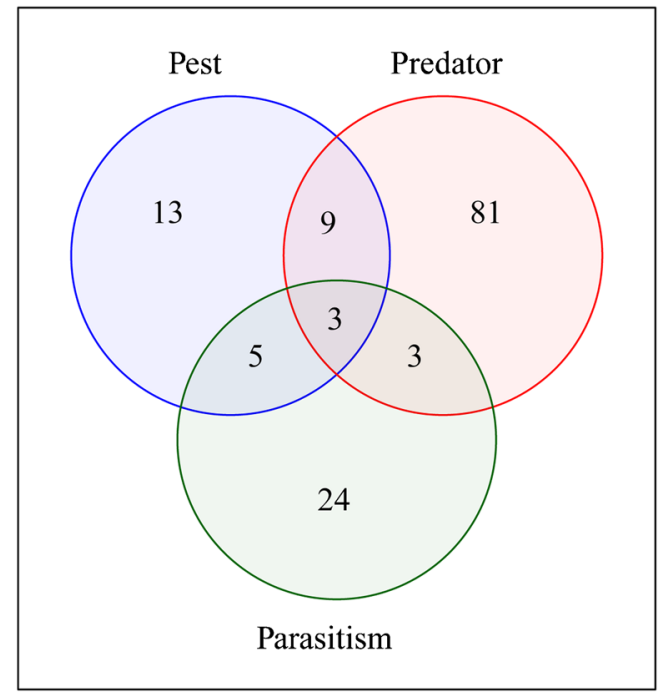

Fig. 10 Number of publications separated by the service providers that were measured predators or parasitism (67\%) was used as a proxy for pest control and pest levels were only measured in $10 \%$. A negative effect was found in only three publications, and all of these measured the abundance of predators or parasitism to obtain the recommendation (Fig. 9). Most positive effects were reported for arable crops but also for other systems. Only two publications reported on yield with one positive finding and the other both negative and positive effects of semi-natural habitats on weed levels.

Whether a positive or negative recommendation was provided was unrelated to the scale of the study. Fifty-eight publications provided a recommendation as to the best seminatural habitats for enhancing pest control which included some landscape-scale studies. Of these publications, $52 \%$ recommended field boundary habitats such as hedgerows, hedgebase or field margins; $17 \%$ recommended cover crops, leys or fallows to enhance pest control; woodland or forest was recommended in $12 \%$ and grassy habitats were recommended in $9 \%$. Some publications recommended more than one habitat type.

Twenty-eight publications reported on whether there was any effect of the interventions on pollination or pollinators, and of these, $79 \%$ reported a positive effect of the landscape, one found a negative response and 5\% no effect (Fig. 9). In all but one study, however, pollination itself was not measured but abundance of pollinators and floral resources instead. Those studies found an increase in pollinators or floral resources after interventions and assumed it to be positively 
Fig. 11 Number of times in which different invertebrate sampling methods were used in the crop, semi-natural habitat (SNH) or both locations

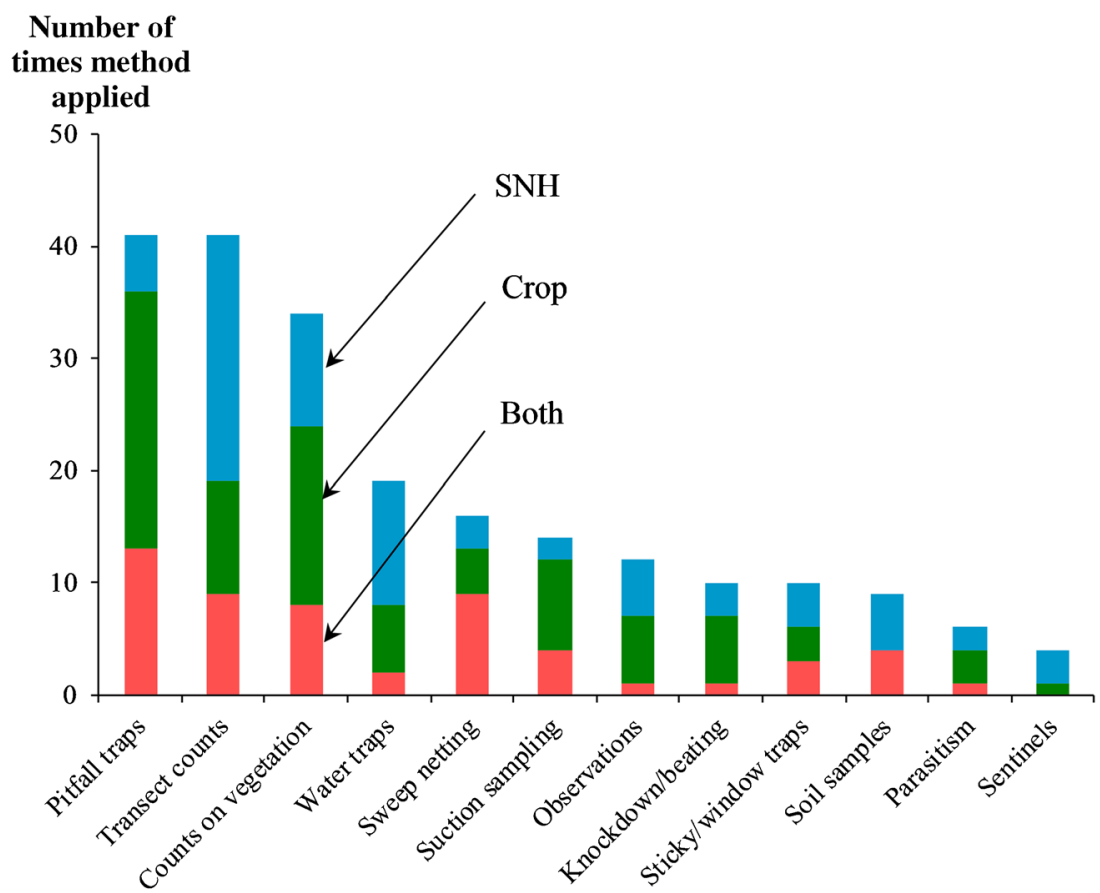

Sampling methods related to pollination. Three times as many of the multi-farmscale publications reported a positive effect compared to single-farm studies. Of those 28 publications reporting an effect of interventions, six recommended field boundary habitats such as hedgerows, hedge base or field margins and seven mentioned that floral abundance was important irrespective of the specific semi-natural habitats. An increase in the area of semi-natural habitats per se was advised in five publications. The negative effect reported occurred in wild cherry trees where increasing vegetation complexity around the trees decreased bee species richness and crop flower visitation rates.

Of the 10 publications investigating soil erosion, eight reported a positive effect of semi-natural habitats and one no effect. In 17 publications, a positive effect on soil organic matter was found whilst two reported no effect. In the 15 publications that provided a recommendation on ways to increase soil organic matter, seven recommended using grass leys, two using
Fig. 12 The number and percentage of publications for each type of service provider
No. publications

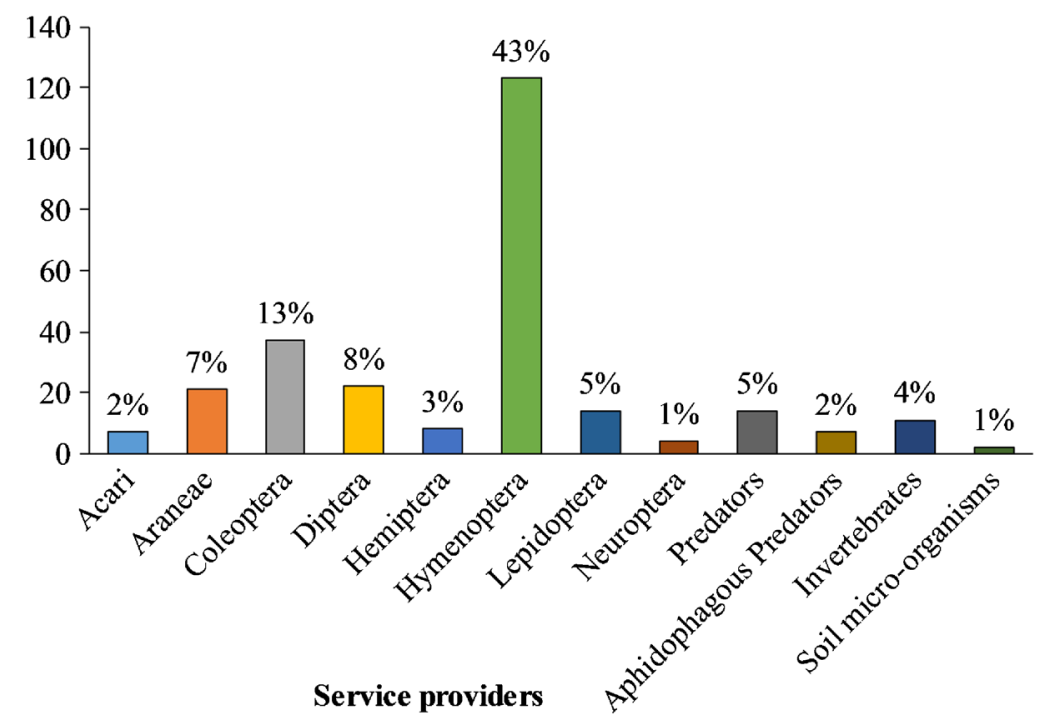


fallows and four using cover crops. Woodland and hedgerows were also found to have high soil organic matter.

\section{Conclusions}

The systematic map revealed that the majority of the publications found a positive effect of semi-natural habitats on pollination and pest control or their proxies, although there were some weaknesses to the evidence base. The study design and sampling methodology varied largely across studies, which were conducted in a limited number of countries and crops. Yield was not measured in any of the pest control studies nor were metrics such as reduced pesticide use that are valued by end users. Likewise for pollination, only $24 \%$ of publications measured a metric of pollination such as pollen deposition or measures that end users are interested in such as seed quality, fruit set or quality (Bommarco et al. 2012). To some ex- tent, these omissions are because the studies were not designed to measure ecosystem services. Yet, they can provide a useful indication of what further information may be gained in future studies.

\subsection{Extending the geographic extent of ecosystem services research across Europe}

The systematic map revealed that biocontrol, pollination and soil conservation have been relatively poorly investigated in most European countries with only five having more than 20 publications suitable for inclusion. There may be many different reasons for this geographic bias, apart from the size of the countries' research community, funding opportunities or publication in national languages. The great majority of publications were from Germany followed by Spain, France, Sweden and Switzerland, whilst Eastern Europe and the far south of Europe were poorly represented. This may be a reflection on the types of landscapes that occur in Western Europe where there has been a history of smaller farms and fields, surrounded by distinct boundary types or woodland, as opposed to Eastern Europe where large state farms predominated during the twentieth century. Thus, the geographical bias in the evidence base prevents researchers from generalising effectively across pedo-climatic zones. If further studies were conducted to allow generalisation across pedoclimatic zones, this would give insight into the role of seminatural habitats on pest control and pollination across Europe. For some services, it may be prudent to focus on those that are particularly relevant to the pedo-climatic zone, for example, some zones may be more susceptible to soil erosion.

\subsection{Ways of improving ecosystem service delivery}

The most heavily investigated semi-natural habitats were hedgerows or other field boundary habitats, woodland and grassland as these represent the main areas of non-crop land on farmland.
For these semi-natural habitats, the abundance of service providers was typically measured. This provided some indication of the resource potential of the habitats, yet if the semi-natural habitat is studied in interaction with the crop and its surrounding landscape, a better understanding of ecosystem services provisioning may be gained. This is because there will be local and landscape influences on ecosystem services provision due to, for example, differences in the mobility of the various service providers (Tscharntke et al. 2005). For less mobile providers, it is the interchange between the semi-natural habitats and the adjacent crop that may determine the level of ecosystem services provision (Bianchi et al. 2006). For more mobile service providers such as bumblebees and hoverflies, it is important to consider the surrounding landscapes that may provide additional service providers to those of local semi-natural habitats.

Different experimental approaches are needed to evaluate local and landscape effects. At the local level, it is valuable to determine the zone of influence of semi-natural habitats yet such studies are difficult and costly to conduct, relying on extensive sampling networks and service providers that exhibit a degree of gradation from the habitat edge into the crop or across the landscape (for examples, see Holland et al. 1999; Holland et al. 2005). That explains why these studies are less frequently conducted, and instead, spatially explicit individual-based models are employed, although these still require realistic data on the service provider's mobility (Bianchi and van der Werf 2003). Tracking the movement of individuals is sometimes feasible either by marking physically (Holland et al. 2004; Winder et al. 2005), using chemical markers such a Rubidium (Tillman et al. 2007) or for larger insects using a tracking device (Tahir and Brooker 2011). All of these require considerably more resources. Directional trapping using window, sticky or pitfall traps can also be employed for some species (Winder et al. 2001; Muirhead-Thomson 1991) to show movement in or out of habitats. Sampling for ecosystem services providers was conducted in crops adjacent to semi-natural habitats and/or the semi-natural habitat. When appraising the value of seminatural habitats adjacent to different crops, the crop management should also be taken into account because there is some evidence that this can also influence service providers within adjacent semi-natural habitats (Rand et al. 2006).

For landscape-scale studies, the influence of landscape composition has been widely investigated and the literature on this periodically reviewed for biocontrol (e.g. Bianchi et al. 2006; Tscharntke et al. 2007, 2012; Chaplin-Kramer et al. 2011) and pollination and pollinators (Viana et al. 2012). Meta-analyses were also conducted to examine the effects of landscape and local features on the comparative abundance of pollinators and natural enemies (Shackelford et al. 2013; Rusch et al. 2014) and on levels of pest control (Rusch et al. 2016). Evidence from these studies can be contradictory, but is not surprising given the complexity of the ecosystems and number of interacting factors that eventually determine the level of ecosystem service 
that is provided. In addition, these studies typically make use of existing landscapes with contrasting levels of landscape composition that may have unforeseen and unaccountable influences on the service provision. For example, the metric of the proportion of non-crop habitats (or cropped area) is commonly used and related to the level of ecosystem service provision. Yet, the composition of the non-crop areas may differ considerably and some types may be more influential than others. More compelling evidence could be gained from manipulations of existing farms or landscapes with ecosystem services evaluations pre and post habitat enhancement. Such designs were only used in $11 \%$ of publications. However, we were unable to identify if specific designs led to stronger recommendations because positive effects were predominantly reported. Metaanalyses, more detailed landscape mapping (García-Feced et al. 2015) and use of spatial models (Ekroos et al. 2014) may help in identifying if there are optimal designs for utilising the ecosystem services supported by semi-natural habitats.

\subsection{Filling the gaps}

\subsubsection{Crops}

This investigation revealed that arable crops, predominantly cereals and oilseed rape, were the most heavily investigated whilst those for which pests and pollination are more important (orchards and vegetable crops) were less frequently studied. This may be because horticultural crops occupy less land and are economically less important in the countries conducting most of the research. In addition, the development of integrated pest management is more problematic for highvalue crops with stringent cosmetic quality targets. On the other hand, such a finding may indicate that research is not being driven by end user requirements.

\subsubsection{Interactions between ecosystem services}

More than one ecosystem service was rarely investigated in the same publication. It may be that other ecosystem services were investigated but published elsewhere; however, these findings suggest that there could be potential to investigate trade-offs between services and to include disservices. If semi-natural habitats are to be optimally utilised, it is essential that trade-offs are understood as they may be beneficial or disadvantageous (Rodriguez et al. 2006).

\subsubsection{Yield}

The majority of publications examined supporting ecosystem services, notably pest control and/or pollination, which is to be expected as most semi-natural habitats occur outside of the crop and these services rely on mobile agents that will benefit from semi-natural habitat enhancement. Yield was only examined in 13 publications despite its importance. This may be because yield is affected by many other inputs including levels of agrochemical inputs, crop variety, water availability, soil type and environmental conditions that may have a much larger impact than that of the service. Moreover, such factors may vary considerably between plots or fields that were chosen to provide a particular habitat and not to standardise management inputs for example, therefore making it difficult to ascertain any difference in yield attributable to a supporting service alone. Nevertheless, many of these other variables can be accounted for using an appropriate design. However, the majority of studies were of 1-year duration even though many factors that influence the level of service provision are likely to vary considerably between years, such as the weather, levels of invertebrate service providers, disease and pest pressure. More long-term experiments are therefore needed.

Impacts on pests or yield are the most compelling evidence for farmers and are needed if wider adoption of semi-natural habitats for pest control is to be advocated. Of the publications that investigated insect pest control, the emphasis was on measurement of service providers and only $22 \%$ measured pest levels. Yield was not measured for pest control studies, yet 57 publications made recommendations on the value of semi-natural habitats for pest control. Most predation publications focussed on insect pests and only five publications were included in the map that investigated seed predation in relation to semi-natural habitats, despite the agronomic importance of weeds. The proportion of sales accounted for by insecticides was less than $5 \%$ in most EU countries whereas sales of herbicides were usually over $50 \%$ and reached $80 \%$ in some countries (Eurostat 2016). These findings and the EU policies on Sustainable Use of Pesticides indicate that further research is needed, incorporating that measurements of impact on either yield or suitable surrogates are needed if farmers are to move towards IPM utilising conservation biocontrol.

\subsubsection{Pollination}

Pollination was investigated in 78 publications of which only six measured pollen transfer or pollinator foraging activity on flowers, with a further 14 measuring seed or fruit set. Most measured pollinators as a surrogate for pollination. There is consequently a knowledge gap for measurement of pollination and its effect on yield with respect to the value of semi-natural habitats. With respect to the study of pollination itself, there is also a need for the development and use of standardised methods as recommended by Liss et al. (2013).

The majority of publications of pest control and pollination focussed on measurements of the service providers whereas few also measured factors that determine their abundance, such as the type and quality of the vegetation in the semi- 
natural habitats. As a consequence, identification of plant species or traits that are particularly beneficial are seldom made (Lavorel et al. 2011), nor are recommendations on how to create or improve semi-natural habitats.

\subsubsection{Seldom investigated ecosystem services}

Few other ecosystem services have been investigated in relation to semi-natural habitats, but these included levels of soil organic matter or carbon storage that reflect carbon sequestration, soil erosion that impacts on water quality, nutrient levels as a measure of nutrient cycling and the aesthetic value of semi-natural habitats. There was evidence that semi-natural habitats stored carbon and helped prevent soil erosion. The role of soil organisms in pest control, carbon sequestration, nutrient cycling and erosion was seldom investigated. All of these areas require further investigation.

\subsection{Recommendations for improving ecosystem services delivery}

Agriculture has been long reliant on artificial agrochemical inputs, and farmers may be reluctant to adopt alternative pest control strategies whilst such inputs remain relatively cheap and reliable. As a consequence, there has not been much pressure to develop alternative techniques and it is only recently with changes in legislation and the advent of more widespread insecticide resistance that alternatives are being investigated. Yet, the most compelling evidence on the benefits of seminatural habitats will come from measures on yield, pesticide use, level of pollination and/or seed quality.

Despite this, it was apparent from this review that many of the publications focussed on one aspect of ecosystem services, such as abundance of service providers rather than the ecosystem services delivery. This was in part because the studies had a different focus, such as nature conservation, rather than ecosystem services delivery. However, even where an ecosystem service was the focus, there was often a tendency to focus on the service providers and typically those that are easiest to sample and identify are most prolific or are typically used as indicators rather than focussing on end user requirements. By measuring the ecosystem service itself (yield, pest control, pesticide use, or level of pollination, seed quality), more persuasive evidence may be gained. In addition, there is a need to harmonise data collection with standard methodologies so that studies can be compared and integrated. This will include selecting metrics that are biologically meaningful and developing indices that can advise us when, for example, sufficient service providers are present. The development of rapid assessment methods would also help reduce the sampling effort per unit resource.

If more resources become available or if sampling becomes more efficient, we recommend to focus on the following:
1. Measuring the ecosystem services, including year-to-year variability, rather than only service providers to generate recommendations for end users

2. Investigations that include more than one ecosystem services including disservices so that trade-offs can be identified

3. Extending the geographical scope of studies to Eastern Europe because at present the majority are from Western Europe

4. The impact of semi-natural habitats in preventing the movement of soil and water. This was identified as a knowledge gap. In addition, the potential of semi-natural habitats to sequester carbon was rarely measured, although there was evidence that soil organic matter and thereby carbon storage is higher than in the surrounding fields (Walter et al. 2003).

5. Study the effectiveness of semi-natural habitats in relation to the (trait) composition of crops and non-crop habitats in the landscape (e.g. Lavorel et al. 2011)

6. Developing proxies that are easier to measure yet still give insight if semi-natural habitats are advantageous (see discussion earlier) and need to be stimulated through policy

\subsection{Recommendations/notes for policymakers}

Knowledge exchange for policymaking should be a two-way process; policymakers need reliable advice that is evidence based, and the policymakers should work with researchers and practitioners to develop research priorities.

This work suggests that policymakers could call for the following:

1. Estimation of how effective semi-natural habitats are at providing ecosystem services such as food production, pest control, pollination and soil preservation. For farmers, some estimate of the reliability and risk associated with more reliance on ecosystem services would also be needed if they are to be encouraged to adopt more sustainable farming practices reliant on ecosystem services (Duru et al. 2015). The predominance of shortterm studies of 1-3-year duration does little to help meet this requirement. Research funders need to recognise that ecosystems change slowly and that longer-term support is needed.

2. Some semi-natural habitats in EU member states are supported through agri-environment scheme funding, and therefore, economic evaluations of the costs and benefits of semi-natural habitats to ecosystem services would help in the justification for this spend. Other habitats that are not supported yet may be important need to be identified and measures put in place to encourage their retention and improvement where necessary. 
Caveat: the authors acknowledge that although the search terms used were devised to identify all relevant publications, they were not comprehensive and therefore may not cover the entire record. Moreover, only those papers that met the inclusion criteria, which was subjective to some extent, were included in the systematic map and other publications exist that also investigated aspects of these ecosystem services.

Acknowledgements The review formed part of the QuESSA project that received funding from the European Union's Seventh Framework Programme for research, technological development and demonstration under grant agreement No. 311879. JCD was supported by an NWO Earth and Life Sciences (NWO-ALW) VENI grant project 863.14.018.

\section{List of European countries included in the search terms and number of publications found per country}

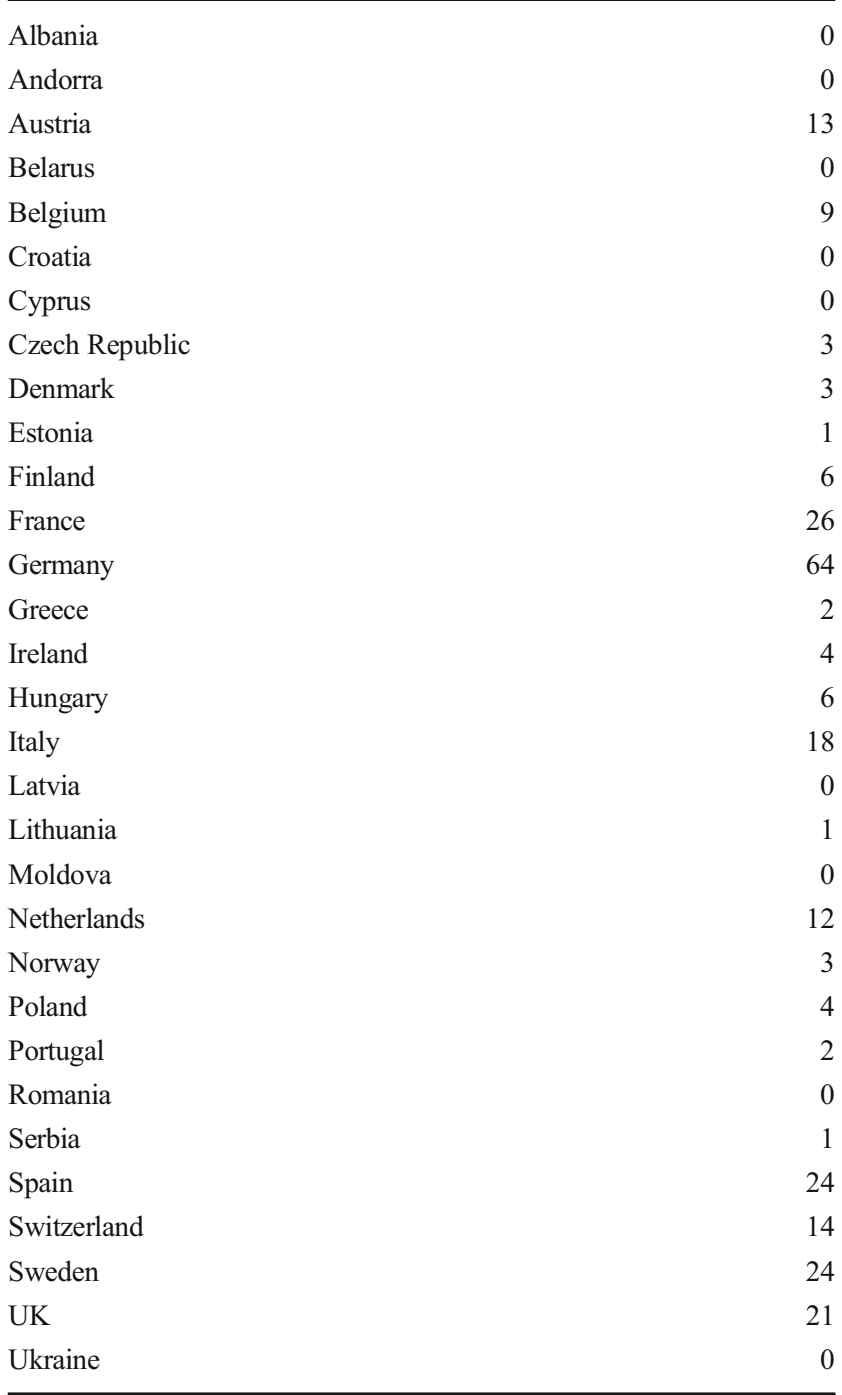

\section{References}

Bianchi FJJA, van der Werf W (2003) The effect of the area and configuration of hibernation sites on the control of aphids by Coccinella septempunctata (Coleoptera : Coccinellidae) in agricultural landscapes: a simulation study. Environ Entomol 32:1290-1304. doi: 10.1603/0046-225X-32.6.1290

Bianchi FJJA, Booij CJH, Tscharntke T (2006) Sustainable pest regulation in agricultural landscapes: a review on landscape composition, biodiversity and natural pest control. Proc R Soc Biol Sci Ser B 273: 1715-1727. doi:10.1098/rspb.2006.3530

Bommarco R, Marini L, Vaissiere BE (2012) Insect pollination enhances seed yield, quality, and market value in oilseed rape. Oecologia (Berl) 169:1025-1032. doi:10.1007/s00442-012-2271-6

Chaplin-Kramer R, O'Rourke ME, Blitzer EJ, Kremen C (2011) A metaanalysis of crop pest and natural enemy response to landscape complexity. Ecol Lett 14:922-932. doi:10.1111/j.1461-0248.2011. 01642

Duru M, Therond O, Martin G, Martin-Clouaire R, Magne M-A, Justes E, Journet E-P, Aubertot J-N, Savary S, Bergez J-E, Sarthou JP (2015) How to implement biodiversity-based agriculture to enhance ecosystem services: a review. Agron Sustain Dev 35:1259-1281. doi: 10.1007/s13593-015-0306-1

Ekroos J, Olsson O, Rundlöf M, Wätzold F, Smith HG (2014) Optimizing agri-environment schemes for biodiversity, ecosystem services or both? Biol Conserv 172:65-71. doi:10.1016/j.biocon.2014.02.013

Eurostat (2016) http://ec.europa.eu/eurostat/statistics-explained/index. php/Agri-environmental_indicator_-_consumption_of_pesticides

García-Feced C, Weissteiner CJ, Baraldi A, Paracchini ML, Maes J, Zulian G, Kempen M, Elbersen B, Pérez-Soba M (2015) Seminatural vegetation in agricultural land: European map and links to ecosystem service supply. Agron Sustain Dev 35:273-283. doi:10. 1007/s13593-014-0238-1

Grant MJ, Booth A (2009) A typology of reviews: an analysis of 14 review types and associated methodologies. Health Inf Libr J 26: 91-108. doi:10.1111/j.1471-1842.2009.00848

Holland JM, Perry JN, Winder L (1999) The within-field spatial and temporal distribution of arthropods in winter wheat. Bull Entomol Res 89:499-513. doi:10.1017/S0007485399000656

Holland J, Begbie M, Birkett T, Southway S, Thoms S, Alexander C, Thomas C (2004) The spatial dynamics and movement of Pterostichus melanarius and P. madidus (Carabidae) between and within arable fields in the UK. Int J Ecol Environ Sci 30:35-50

Holland JM, Thomas C, Birkett T, Southway S, Oaten H (2005) Farmscale spatiotemporal dynamics of predatory beetles in arable crops. J Appl Ecol 42:1140-1152. doi:10.1111/j.1365-2664.2005.01083

Holland JM, Jeanneret P, Herzog F, Moonen A-C, Rossing W, van der Werf W, Kiss J, van Helden M, Paracchini ML, Cresswell J, Pointereau P, Heijne B, Veromann E, Antichi D, Entling M, Balázs B (2014) The QuESSA project: quantification of ecological services for sustainable agriculture. Landscape Management for Functional Biodiversity International Organisation for Biological Control/West Palaearctic Regional Section Bulletin 100:55-58

Holland JM, Bianchi FJJA, Entling MH, Moonen AC, Smith BM, Jeanneret P (2016) Structure, function and management of seminatural habitats for conservation biological control: a review of European studies. Pest Manag Sci 72:1638-1651. doi:10.1002/ps. 4318

James KL, Randall NP, Haddaway NR (2016) A methodology for systematic mapping in environmental sciences. Environ Evidence 5. doi:10.1186/s13750-016-0059-6

Keenleyside C, Allen B, Hart K, Menaude H, Stefanova V, Prazan J, Herzon I, Clement T, Povellato A, Maciejczak M, Boatman N (2011) Delivering environmental benefits through entry level agrienvironment schemes in the EU. Report prepared for DG 
Environment, Project ENV.B.1/ETU/2010/0035. Institute for European Environmental Policy, London

Kleijn D, Baquero RA, Clough Y, Diaz M, De Esteban J, Fernandez F, Gabriel D, Herzog F, Holzschuh A, Johl R, Knop E, Kruess A, Marshall EJP, Steffan-Dewenter I, Tscharntke T, Verhulst J, West TM, Yela JL (2006) Mixed biodiversity benefits of agrienvironment schemes in five European countries. Ecol Lett 9:243254. doi:10.1111/j.1461-0248.2005.00869

Landis DA, Wratten SD, Gurr GM (2000) Habitat management to conserve natural enemies of arthropod pests in agriculture. Ann Rev Entomol 45:175-201. doi:10.1146/annurev.ento.45.1.175

Lavorel S, Grigulis K, Lamarque P, Colace M-P, Garden D, Girel J, Pellet G, Douzet R (2011) Using plant functional traits to understand the landscape distribution of multiple ecosystem services. J Ecol 99: 135-147. doi:10.1111/j.1365-2745.2010.01753

Liss KN, Mitchell MGE, MacDonald GK, Mahajan SL, Méthot J, Jacob AL, Maguire DY, Metson GS, Ziter C, Dancose K, Martins K, Terrado M, Bennett EM (2013) Variability in ecosystem service measurement: a pollination service case study. Front Ecol Environ 11:414-422. doi:10.1890/120189

Lowrance R, Dabney S, Schultz R (2002) Improving water and soil quality with conservation buffers. J Soil Water Conserv 57:36A$43 \mathrm{~A}$

Muirhead-Thomson RC (1991) Flight traps and interceptor traps. In: Muirhead-Thomson RC (ed) Trap responses of flying insects: the influence of trap design on capture efficiency. Academic Press, London, pp 152-179

Rand TA, Tylianakis JM, Tscharntke T (2006) Spillover edge effects: the dispersal of agriculturally subsidized insect natural enemies into adjacent natural habitats. Ecol Lett 9:603-614. doi:10.1111/j.14610248.2006.00911

Rodriguez E, Fernandez-Anero FJ, Ruiz P, Campos M (2006) Soil arthropod abundance under conventional and no tillage in a Mediterranean climate. Soil Tillage Res 85:229-233. doi:10.1016/j.still.2004.12. 010

Rusch A, Birkhofer K, Bommarco R, Smith HG, Ekbom B (2014) Management intensity at field and landscape levels affects the structure of generalist predator communities. Oecologia 175:971-983. doi:10.1007/s00442-014-2949

Rusch A, Chaplin-Kramer R, Gardiner MM, Hawro V, Holland J, Landis D, Thies C, Tscharntke T, Weisser WW, Winqvist C, Woltz M, Bommarco R (2016) Agricultural landscape simplification reduces natural pest control: a quantitative synthesis. Agric Ecosyst Environ 221:198-204. doi:10.1007/s10980-016-0390

Shackelford G, Steward PR, Benton TG, Kunin WE, Potts SG, Biesmeijer JC, Sait SM (2013) Comparison of pollinators and natural enemies: a meta-analysis of landscape and local effects on abundance and richness in crops. Biol Rev 88:1002-1021. doi:10.1111/ brv. 12040

Tahir N, Brooker G (2011) Recent developments and recommendations for improving harmonic radar tracking systems. In: Proceedings of the 5th European Conference on Antennas and Propagation (EUCAP), 11-15 April 2011, pp 1531-1535

Thies C, Tscharntke T (1999) Landscape structure and biological control in agroecosystems. Science 285:893-895. doi:10.1126/science.285. 5429.893

Tillman PG, Prasifka JR, Heinz KM (2007) Rubidium marking to detect dispersal of pest and predator from corn into sorghum and cotton in Georgia. J Entomol Sci 42:383-391

Tscharntke T, Rand TA, Bianchi FJJA (2005) The landscape context of trophic interactions: insect spillover across the crop-noncrop interface. Ann Zool Fenn 42:421-432

Tscharntke T, Bommarco R, Clough Y, Crist TO, Kleijn D, Rand TA, Tylianakis JM, van Nouhuys S, Vidal S (2007) Conservation biological control and enemy diversity on a landscape scale. Biol Control 43:294-309. doi:10.1016/j.biocontrol.2007.08.006
Tscharntke T, Tylianakis JM, Rand TA, Didham RK, Fahrig L, Peter B, Bengtsson J, Clough Y, Crist TO, Dormann CF, Ewers RM, Fruend J, Holt RD, Holzschuh A, Klein AM, Kleijn D, Kremen C, Landis DA, Laurance W, Lindenmayer D, Scherber C, Sodhi N, SteffanDewenter I, Thies C, van der Putten WH, Westphal C (2012) Landscape moderation of biodiversity patterns and processes - eight hypotheses. Biol Rev (Camb) 87:661-685. doi:10.1111/j.1469185X.2011.00216

Viana BF, Boscolo D, Neto E, Lopes L, Lopes A, Ferreira PA, Pigozzo C, Primo L (2012) How well do we understand landscape effects on pollinators and pollination services? J Pollinat Ecol 7:31-42

Vihervaara P, Rönkä M, Walls M (2010) Trends in ecosystem service research: early steps and current drivers. Ambio 39:314-324. doi: 10.1007/s13280-010-0048

Walter C, Merot P, Layer B, Dutin G (2003) The effect of hedgerows on soil organic carbon storage in hillslopes. Soil Use Manage 19:201207. doi:10.1079/sum 2002190

Winder L, Holland JM, Perry JN, Woolley C, Alexander CJ (2001) The use of barrier-connected pitfall trapping for sampling predatory beetles and spiders. Entomol Exp Appl 98:249-258. doi:10.1046/j. 1570-7458.2001.00781

Winder L, Alexander CJ, Holland JM, Symondson WO, Perry JN, Woolley C (2005) Predatory activity and spatial pattern: the response of generalist carabids to their aphid prey. J Anim Ecol 74: 443-454. doi:10.1111/j.1365-2656.2005.00939

Wratten SD, Gillespie M, Decourtye A, Mader E, Desneux N (2012) Pollinator habitat enhancement: benefits to other ecosystem services. Agric Ecosyst Environ 159:112-122. doi:10.1016/j.agee. 2012.06.020

van Zanten BT, Verburg PH, Espinosa M, Gomez-y-Paloma S, Galimberti G, Kantelhardt J, Kapfer M, Lefebvre M, Manrique R, Piorr A, Raggi M, Schaller L, Targetti S, Zasada I, Viaggi D (2014) European agricultural landscapes, common agricultural policy and ecosystem services: a review. Agron Sustain Dev 34:309-325. doi: 10.1007/s13593-013-0183-4

References of the systematic map

Aguilar-Fenollosa E, Ibáñez-Gual MV, Pascual-Ruiz S, Hurtado M, Jacas JA (2011a) Effect of ground-cover management on spider mites and their phytoseiid natural enemies in clementine mandarin orchards (I): bottom-up regulation. Biol Control 59:158-170

Aguilar-Fenollosa E, Ibáñez-Gual MV, Pascual-Ruiz S, Hurtado M, Jacas JA (2011b) Effect of ground-cover management on spider mites and their phytoseiid natural enemies in clementine mandarin orchards (II): top-down regulation. Biol Control 2011(59):171-179

Aguilar-Fenollosa E, Pascual-Ruiz S, Hurtado MA, Jacas JA (2011c) Efficacy and economics of ground cover management as a conservation biological control strategy against Tetranychus urticae in clementine mandarin orchards. Crop Prot 30:1328-1333

Ailincăi C, Jităreanu G, Bucur D, Ailincăi D, Mercuş AD (2011) Evolution of some chemical properties of soil under influence of soil erosion and different cropping systems. Cercetari Agronomice in Moldova XLIV, No. 4(148):5-18

Al Hassan D, Georgelin E, Delattre T, Burel F, Plantegenest M, Kindlmann P, Butet A (2013) Does the presence of grassy strips and landscape grain affect the spatial distribution of aphids and their carabid predators? Agric For Entomol 15:24-33

Alanen EL, Hyvönen T, Lindgren S, Härmä O, Kuussaari M (2011) Differential responses of bumblebees and diurnal Lepidoptera to vegetation succession in long-term set-aside. J Appl Ecol 48: $1251-1259$

Albrecht M, Duelli P, Müller C, Kleijn D, Schmid B (2007a) The Swiss agri-environment scheme enhances pollinator diversity and plant 
reproductive success in nearby intensively managed farmland. $\mathrm{J}$ Appl Ecol 44:813-822

Albrecht M, Duelli P, Schmid B, Müller CB (2007b) Interaction diversity within quantified insect food webs in restored and adjacent intensively managed meadows. J Anim Ecol 76:1015-1025

Alcántara C, Pujadas A, Saavedra M (2011) Management of cruciferous cover crops by mowing for soil and water conservation in southern Spain. Agric Water Manag 98:1071-1080

Alebeek F, Kamstra J-H, Kruistum G, Visser A (2006) Improving natural pest suppression in arable farming: field margins and the importance of ground dwelling predators. Landscape Management For Functional Biodiversity, IOBC wprs Bulletin 29:137

Alhmedi A, Haubruge E, Francis F (2011a) Effect of stinging nettle habitats on aphidophagous predators and Hymenoptera in wheat and green pea fields with special attention to the invader Harmonia. Entomological Science 12:349-358

Alhmedi A, Haubruge E, D'Hoedt S, Francis F (2011b) Quantitative food webs of herbivore and related beneficial community in non-crop and crop habitats. Biol Control 58:103-112

Alomar Ò, Goula M, Albajes R (2002) Colonisation of tomato fields by predatory mirid bugs (Hemiptera: Heteroptera) in Northern Spain. Agric Ecosyst Environ 89:105-115

Ameixa OLGA, Kindlmann PAVEL (2008) Agricultural policy-induced landscape changes: effects on carabid abundance and their biocontrol potential. European Journal of Entomology 105:467-476

Andersen A (1997) Densities of overwintering Coleoptera and staphylinids (Col., Carabidae and Staphylinidae) in cereal and grass fields and their boundaries. J Appl Entomol 121:77-80

Anderson A, Carnus T, Helden AJ, Sheridan H, Purvis G (2013) The influence of conservation field margins in intensively managed grazing land on communities of five arthropod trophic groups. Insect Conservation and Diversity 6:201-211

Andersson GK, Ekroos J, Stjernman M, Rundlöf M, Smith HG (2014) Effects of farming intensity, crop rotation and landscape heterogeneity on field bean pollination. Agric Ecosyst Environ 184:145-148

Anjum-Zubair M, Schmidt-Entling MH, Querner P, Frank T (2010) Influence of within-field position and adjoining habitat on carabid beetle assemblages in winter wheat. Agric For Entomol 12:301-306

Anti RS, Gerzabek MH, Haberhauer G, Eder G (2005) Long-term effects of cropped vs. fallow and fertilizer amendments on soil organic matter II. Nitrogen. J Plant Nutr Soil Sci 168:212-218

Antil RS, Gerzabek MH, Haberhauer G, Eder G (2005) Long-term effects of cropped vs. fallow and fertilizer amendments on soil organic matter-I. Organic carbon. Journal of Plant Nutrition And Soil $168: 108-116$

Anyszka Z, Dobrzanski A (2006) Impact of cover crops and herbicides usage on weed infestation, growth and yield of transplanted leek. Journal of Plant Diseases and Protection 20:733-738

Bailey D, Schmidt-Entling MH, Eberhart P, Herrmann JD, Hofer G, Kormann U, Herzog F (2010) Effects of habitat amount and isolation on biodiversity in fragmented traditional orchards. J Appl Ecol 47:1003-1013

Bailey S, Requier F, Nusillard B, Roberts SP, Potts SG, Bouget C (2014) Distance from forest edge affects bee pollinators in oilseed rape fields. Ecology and Evolution 4:370-380

Baraibar B, Westerman PR, Carrión E, Recasens J (2009) Effects of tillage and irrigation in cereal fields on weed seed removal by seed predators. J Appl Ecol 46:380-387

Bartomeus I, Vila M, Steffan-Dewenter I (2010) Combined effects of Impatiens glandulifera invasion and landscape structure on native plant pollination. J Ecol 98:440-450

Bartomeus I, Potts SG, Steffan-Dewenter I, Vaissiere BE, Woyciechowski M, Krewenka KM et al (2014) Contribution of insect pollinators to crop yield and quality varies with agricultural intensification. Peer J 2:e328
Basedow T (1998) The species composition and frequency of Araneae (Araneae) in fields of winter wheat grown under different conditions in Germany. J Appl Entomol 122:585-590

Batáry P, Sutcliffe L, Dormann CF, Tscharntke T (2013) Organic farming favours insect-pollinated over non-insect pollinated forbs in meadows and wheat fields. PLoS One 8:e54818

Bennewicz J (2011) Aphidivorous Diptera (Diptera: Syrphidae) at field boundaries and woodland edges in an agricultural landscape. Polish Journal of Entomology 80:129-149

Berg A, Ahrne K, Ockinger E, Svensson R, Soderstrom B (2011) Butterfly distribution and abundance is affected by variation in the Swedish forest-farmland landscape. Biol Conserv 144:2819-2831

van Berkel DB, Verburg PH (2014) Spatial quantification and valuation of cultural ecosystem services in an agricultural landscape. Ecol Indic 37:163-174

Bianchi FJJA, Van Wingerden WKRE, Griffioen AJ, Van Der Veen M, Van Der Straten MJJ, Wegman RMA, Meeuwsen HAM (2005) Landscape factors affecting the control of Mamestra brassicae by natural enemies in Brussel sprout. Agric Ecosyst Environ 107:145150

Bianchi FJJA, Goedhart PW, Baveco JM (2008) Enhanced pest control in cabbage crops near forest in The Netherlands. Landsc Ecol 23:595602

Birge T, Fred M (2011) New ideas for old landscapes: using a socialecological approach for conservation of traditional rural biotopes-a case study from Finland. European Countryside 3:51-67

Boccaccio L, Petacchi R (2009) Landscape effects on the complex of Bactrocera oleae Hymenoptera and implications for conservation biological control. BioControl 54:607-616

Bodner G, Loiskandl W, Buchan G, Kaul HP (2008) Natural and management-induced dynamics of hydraulic conductivity along a cover-cropped field slope. Geoderma 146:317-325

Bodner G, Himmelbauer M, Loiskandl W, Kaul HP (2010) Improved evaluation of cover crop species by growth and root factors. Agron Sustain Dev 30:455-464

Boller EF, Remund U, Candolfi MP (1988) Hedges as potential sources of Typhlodromus pyri, the most important predatory mite in vineyards of Northern Switzerland. Entomophaga 33:249-255

Bommarco R, Marini L, Vaissière BE (2012) Insect pollination enhances seed yield, quality, and market value in oilseed rape. Oecologia 169: 1025-1032

Bonte D, Lanckacker K, Wiersma E, Lens L (2008) Web building flexibility of an orb-web spider in a heterogeneous agricultural landscape. Ecography 31:646-653

Borin M, Passoni M, Thiene M, Tempesta T (2010) Multiple functions of buffer strips in farming areas. Eur J Agron 32:103-111

Boulal H, Gómez-Macpherson H (2010) Dynamics of soil organic carbon in an innovative irrigated permanent bed system on sloping land in southern Spain. Agric Ecosyst Environ 139:284-292

Breitbach N, Tillmann S, Schleuning M, Grünewald C, Laube I, SteffanDewenter I, Böhning-Gaese K (2012) Influence of habitat complexity and landscape configuration on pollination and seed-dispersal interactions of wild cherry trees. Oecologia 168:425-437

Brittain C, Bommarco R, Vighi M, Settele J, Potts SG (2010) Organic farming in isolated landscapes does not benefit flower-visiting insects and pollination. Biol Conserv 143:1860-1867

Burgio G, Ferrari R, Pozzati M, Boriani L (2004) The role of ecological compensation areas on predator populations: an analysis on biodiversity and phenology of Coleoptera (Coleoptera) on non-crop plants within hedgerows in Northern Italy. Bulletin of Insectology 57:1-10

Buri P, Humbert JY, Arlettaz R (2014) Promoting pollinating insects in intensive agricultural matrices: field-scale experimental manipulation of hay-meadow mowing regimes and its effects on Hymenoptera. PLoS One 9:e85635 
Caballero-López B, Bommarco R, Blanco-Moreno JM, Sans FX, PujadeVillar J, Rundlöf M, Smith HG (2012) Aphids and their natural enemies are differently affected by habitat features at local and landscape scales. Biol Control 63:222-229

Cammeraat EL (2004) Scale dependent thresholds in hydrological and erosion response of a semi-arid catchment in southeast Spain. Agric Ecosyst Environ 104:317-332

Campiglia E, Mancinelli R, Radicetti E, Caporali F (2010) Effect of cover crops and mulches on weed control and nitrogen fertilization in tomato (Lycopersicon esculentum mill.) Crop Prot 29:354-363

Carré G, Roche P, Chifflet R, Morison N, Bommarco R, Harrison-Cripps $\mathrm{J}$ et al (2009) Landscape context and habitat type as drivers of bee diversity in European annual crops. Agric Ecosyst Environ 133:40 47

Carvell C, Meek WR, Pywell RF, Goulson D, Nowakowski M (2007) Comparing the efficacy of agri-environment schemes to enhance bumble bee abundance and diversity on arable field margins. J Appl Ecol 44:29-40

Carvell C, Osborne JL, Bourke AFG, Freeman SN, Pywell RF, Heard MS (2011) Bumble bee species' responses to a targeted conservation measure depend on landscape context and habitat quality. Ecol Appl 21:1760-1771

Casalí J, Gastesi R, Álvarez-Mozos J, De Santisteban LM, Lersundi J, Giménez R et al (2008) Runoff, erosion, and water quality of agricultural watersheds in central Navarre (Spain). Agric Water Manag 95:1111-1128

Castro J, Fernandez-OndoNo E, Rodriguez C, Lallena AM, Sierra M, Aguilar J (2008) Effects of different olive-grove management systems on the organic carbon and nitrogen content of the soil in Jaen (Spain). Soil Tillage Res 98:56-67

Chifflet R, Klein EK, Lavigne C, Le Feon V, Ricroch AE, Lecomte J, Vaissiere BE (2011) Spatial scale of insect-mediated pollen dispersal in oilseed rape in an open agricultural landscape. J Appl Ecol 48: 689-696

Clough Y, Kruess A, Kleijn D, Tscharntke T (2005) Spider diversity in cereal fields: comparing factors at local, landscape and regional scales. J Biogeogr 32:2007-2014

Clough Y, Kruess A, Tscharntke T (2007) Local and landscape factors in differently managed arable fields affect the insect herbivore community of a non-crop plant species. J Appl Ecol 44:22-28

Constantin J, Mary B, Laurent F, Aubrion G, Fontaine A, Kerveillant P, Beaudoin N (2010) Effects of catch crops, no till and reduced nitrogen fertilization on nitrogen leaching and balance in three long-term experiments. Agric Ecosyst Environ 135:268-278

Cotes B, Campos M, Pascual F, Ruano F (2010) The ladybeetle community (Coleoptera: Coleoptera) in southern olive agroecosystems of Spain. Environ Entomol 39:79-87

Cranmer L, McCollin D, Ollerton J (2012) Landscape structure influences pollinator movements and directly affects plant reproductive success. Oikos 121:562-568

Daedlow D, Sommer T, Westermann PR (2012) Weed seed predation in organic and conventional cereal fields. Julius-Kühn-Archiv 434:265

Dalin P (2006) Habitat difference in abundance of willow leaf beetle Phratora vulgatissima (Coleoptera: Chrysomelidae): plant quality or natural enemies? Bull Entomol Res 96:629-635

Dauber J, Biesmeijer JC, Gabriel D, Kunin WE, Lamborn E, Meyer B et al (2010) Effects of patch size and density on flower visitation and seed set of wild plants: a pan-European approach. J Ecol 98:188196

De Cauwer, B (2005) Biodiveristy and agro-ecology in field margins. $\mathrm{PhD}$ Thesis, Faculty of Bioscience Engineering, Universiteit Gent

Debras JF, SeNoussi R, Rieux R, Buisson E, Dutoit T (2008) Spatial distribution of an arthropod community in a pear orchard (southern France)-identification of a hedge effect. Agric Ecosyst Environ 127:166-176
Debras J, Senoussi R, Dutoit T (2010) Hedgerow effects on the distribution of beneficial arthropods in a pear orchard in Southern France. Revue Internationale D'écologie Méditerranéenne International Journal of Mediterranean Ecology 37:75-82

Dennis P, Fry GLA (1992) Field margins - can they enhance natural enemy population-densities and general arthropod diversity on farmland. Agric Ecosyst Environ 40:95-115

Denys C, Tscharntke T (2002) Plant-insect communities and predatorprey ratios in field margin strips, adjacent crop fields, and fallows. Oecologia 130:315-324

Díaz M (1992) Spatial and temporal patterns of granivorous ant seed predation in patchy cereal crop areas of central Spain. Oecologia 91:561-568

Diehl E, Mader VL, Wolters V, Birkhofer K (2013) Management intensity and vegetation complexity affect web-building Araneae and their prey. Oecologia 173:579-589

Diekötter T, Walther-Hellwig K, Conradi M, Suter M, Frankl R (2006) Effects of landscape elements on the distribution of the rare bumblebee species Bombus muscorum in an agricultural landscape. Biodivers Conserv 15:57-68

Diekötter T, Kadoya T, Peter F, Wolters V, Jauker F (2010) Oilseed rape crops distort plant-pollinator interactions. J Appl Ecol 47:209-214

Ditner N, Balmer O, Beck J, Blick T, Nagel P, Luka H (2013) Effects of experimentally planting non-crop flowers into cabbage fields on the abundance and diversity of predators. Biodivers Conserv 22:10491061

Drapela T, Moser D, Zaller JG, Frank T (2008) Spider assemblages in winter oilseed rape affected by landscape and site factors. Ecography 31:254-262

Drapela T, Frank T, Heer X, Moser D, Zaller JG (2011) Landscape structure affects activity density, body size and fecundity of Pardosa wolf Araneae (Araneae: Lycosidae) in winter oilseed rape. European Journal of Entomology 108:609-614

Duso C, Malagnini V, Paganelli A, Aldegheri L, Bottini M, Otto S (2004) Pollen availability and abundance of predatory phytoseiid mites on natural and secondary hedgerows. BioControl 49:397-415

Ekroos J, Piha M, Tiainen J (2008) Role of organic and conventional field boundaries on boreal bumblebees and Lepidoptera. Agric Ecosyst Environ 124:155-159

Evans DM, Pocock MJ, Brooks J, Memmott J (2011) Seeds in farmland food-webs: resource importance, distribution and the impacts of farm management. Biol Conserv 144:2941-2950

Fabian Y, Sandau N, Bruggisser OT, Aebi A, Kehrli P, Rohr RP et al (2013) The importance of landscape and spatial structure for Hymenopteran-based food webs in an agro-ecosystem. J Anim Ecol 82:1203-1214

Fabian Y, Sandau N, Bruggisser OT, Aebi A, Kehrli P, Rohr RP et al (2014) Plant diversity in a nutshell: testing for small-scale effects on trap nesting wild Hymenoptera and wasps. Ecosphere 5:1-18

Farwig N, BaiLey D, Bochud E, Herrmann JD, Kindler E, Reusser N et al (2009) Isolation from forest reduces pollination, seed predation and insect scavenging in Swiss farmland. Landsc Ecol 24:919-927

Felipe Lucia M, Comín FA, Bennett EM (2014) Interactions among ecosystem services across land uses in a floodplain agroecosystem. Ecol Soc 19:20

Fischer C, Thies C, Tscharntke T (2011) Mixed effects of landscape complexity and farming practice on weed seed removal. Perspectives in Plant Ecology, Evolution and Systematics 13:297303

Fliszkiewicz M, Kuśnierczak A, Szymaś B (2012) The accompanying fauna of solitary bee Osmia bicornis (L.) Syn. Osmia rufa (L.) nests settled in different biotopes. Journal of Apicultural Science 56:5158

Follain S, Walter C, Legout A, Lemercier B, Dutin G (2007) Induced effects of hedgerow networks on soil organic carbon storage within an agricultural landscape. Geoderma 142:80-95 
Fontana V, Radtke A, Walde J, Tasser E, Wilhalm T, Zerbe S, Tappeiner U (2014) What plant traits tell us: consequences of land-use change of a traditional agro-forest system on biodiversity and ecosystem service provision. Agric Ecosyst Environ 186:44-53

Fournier E, Loreau M (1999) Effects of newly planted hedges on groundbeetle diversity (Coleoptera, Carabidae) in an agricultural landscape. Ecography 22:87-97

Frank T (1999) Density of adult Diptera (Dipt., Syrphidae) in sown weed strips acid adjacent fields. J Appl Entomol 123:351-355

Franzen M, Nilsson SG (2008) How can we preserve and restore species richness of pollinating insects on agricultural land? Ecography 31: 698-708

Gabarra R, Alomar Ò, Castañé C, Goula M, Albajes R (2004) Movement of greenhouse whitefly and its predators between in-and outside of Mediterranean greenhouses. Agric Ecosyst Environ 102:341-348

Gabriel D, Tscharntke T (2007) Insect pollinated plants benefit from organic farming. Agric Ecosyst Environ 118:43-48

Gagic, V, Tscharntke, T, Dormann, CF, Gruber, B, Wilstermann, A, Thies, C (2011) Food web structure and biocontrol in a four-trophic level system across a landscape complexity gradient. Proc R Soc B Biol Sci, rspb20102645

Gagic V, Hänke S, Thies C, Scherber C, Tomanović Ž, Tscharntke T (2012) Agricultural intensification and cereal aphid-parasitoidhyperparasitoid food webs: network complexity, temporal variability and parasitism rates. Oecologia 170:1099-1109

Gagic V, Hänke S, Thies C, Tscharntke T (2014) Community variability in aphid Hymenoptera versus predators in response to agricultural intensification. Insect Conserv Divers 7:103-112

Geiger F, Bianchi FJJA, Wäckers FL (2005) Winter ecology of the cabbage aphid Brevicoryne brassicae (L.)(Homo., Aphididae) and its parasitoid Diaeretiella rapae (McIntosh)(Hym., Braconidae: Aphidiidae). J Appl Entomol 129:563-566

Geiger F, Wackers FL, Bianchi FJJA (2009) Hibernation of predatory arthropods in semi-natural habitats. BioControl 54:529-535

Geslin B, Gauzens B, Thébault E, Dajoz I (2013) Plant pollinator networks along a gradient of urbanisation. PLoS One 8:e63421

Gladbach DJ, Holzschuh A, Scherber C, Thies C, Dormann CF, Tscharntke T (2011) Crop-noncrop spillover: arable fields affect trophic interactions on wild plants in surrounding habitats. Oecologia 166:433-441

Glendell M, Granger SJ, Bol R, Brazier RE (2014) Quantifying the spatial variability of soil physical and chemical properties in relation to mitigation of diffuse water pollution. Geoderma 214:25-41

Goidts E, van Wesemael BAS, Van Oost K (2009) Driving forces of soil organic carbon evolution at the landscape and regional scale using data from a stratified soil monitoring. Glob Chang Biol 15:29813000

Goller E, Nunnenmacher L, Goldbach HE (1997) Faba beans as a cover crop in organically grown hops: influence on aphids and aphid antagonists. Entomol Res Org Agric 15:279-284

Gómez JA, Llewellyn C, Basch G, Sutton PB, Dyson JS, Jones CA (2011) The effects of cover crops and conventional tillage on soil and runoff loss in vineyards and olive groves in several Mediterranean countries. Soil Use Manag 27:502-514

Good JA, Giller PS (1991) The effect of cereal and grass management on staphylinid (Coleoptera) assemblages in south-west Ireland. J Appl Ecol 28:810-826

Haenke S, Scheid B, Schaefer M, Tscharntke T, Thies C (2009) Increasing syrphid fly diversity and density in sown flower strips within simple vs. complex landscapes. J Appl Ecol 46:1106-1114

Haenke S, Kovács-Hostyánszki A, Fründ J, Batáry P, Jauker B, Tscharntke T, Holzschuh A (2014) Landscape configuration of crops and hedgerows drives local syrphid fly abundance. J Appl Ecol 51:505-513

Haschek C, Drapela T, Schuller N, Fiedler K, Frank T (2012) Carabid beetle condition, reproduction and density in winter oilseed rape affected by field and landscape parameters. J Appl Entomol 136: 665-674

Helenius JK, Holopainen JK, Huusela-Veistola E (2008) Ground beetle (Coleoptera, Carabidae) diversity in Finnish arable land. Agric Food Sci 10:261-276

Henriksen CI, Langer V (2013) Road verges and winter wheat fields as resources for wild Hymenoptera in agricultural landscapes. Agric Ecosyst Environ 173:66-71

Henry M, Fröchen M, Maillet-Mezeray J, Breyne E, Allier F, Odoux JF, Decourtye A (2012) Spatial autocorrelation in honeybee foraging activity reveals optimal focus scale for predicting agroenvironmental scheme efficiency. Ecol Model 225:103-114

Hirsch M, Pfaff S, Wolters V (2003) The influence of matrix type on flower visitors of Centaurea jacea L. Agric Ecosyst Environ 98: 331-337

Holland JM, Oaten H, Southway S, Moreby S (2008) The effectiveness of field margin enhancement for cereal aphid control by different natural enemy guilds. Biol Control 47:71-76

Holland JM, Birkett T, Southway S (2009) Contrasting the farm-scale spatio-temporal dynamics of boundary and field overwintering predatory Coleoptera in arable crops. BioControl 54:19-33

Holzschuh A, Steffan-Dewenter I, Kleijn D, Tscharntke T (2007) Diversity of flower-visiting Hymenoptera in cereal fields: effects of farming system, landscape composition and regional context. J Appl Ecol 44:41-49

Holzschuh A, Steffan-Dewenter I, Tscharntke T (2009) Grass strip corridors in agricultural landscapes enhance nest-site colonization by solitary wasps. Ecol Appl 19:123-132

Holzschuh A, Steffan-Dewenter I, Tscharntke T (2010) How do landscape composition and configuration, organic farming and fallow strips affect the diversity of Hymenoptera, wasps and their Hymenoptera? J Anim Ecol 79:491-500

Holzschuh, A, Dormann, CF, Tscharntke, T, Steffan-Dewenter, I (2011) Expansion of mass-flowering crops leads to transient pollinator dilution and reduced wild plant pollination. Proc R Soc B Biol Sci, rspb20110268

Holzschuh A, Dudenhöffer JH, Tscharntke T (2012) Landscapes with wild bee habitats enhance pollination, fruit set and yield of sweet cherry. Biol Conserv 153:101-107

Holzschuh A, Dormann CF, Tscharntke T, Steffan-Dewenter I (2013) Mass-flowering crops enhance wild bee abundance. Oecologia 172:477-484

Hradetzky R, Kromp B (1997) Spatial distribution of flying insects in an organic rye field and an adjacent hedge and forest edge. Entomological Research in Organic Agriculture 15:353-357

Iekarska-Boniecka H, Wilkaniec B, Dolanska-Niedbala E (2008) Parasitic wasps of the Pimplinae subfamily (Hymenoptera, Ichneumonidae) of agricultural landscape refugium habitats in central Wielkopolska. Acta Oecol 7:23-30

Inclán DJ, Cerretti P, Marini L (2014) Interactive effects of area and connectivity on the diversity of tachinid Hymenoptera in highly fragmented landscapes. Landsc Ecol 29:879-889

Jakobsson A, Ågren J (2014) Distance to semi-natural grassland influences seed production of insect-pollinated herbs. Oecologia 175: 199-208

Jankauskas B, Jankauskiene G, Fullen MA (2004) Erosion-preventive crop rotations and water erosion rates on undulating slopes in Lithuania. Can J Soil Sci 84:177-186

Jauker F, Diekotter T, Schwarzbach F, Wolters V (2009) Pollinator dispersal in an agricultural matrix: opposing responses of wild Hymenoptera and Diptera to landscape structure and distance from main habitat. Landsc Ecol 24:547-555

Jonason D, Smith HG, Bengtsson J, Birkhofer K (2013) Landscape simplification promotes weed seed predation by carabid Coleoptera (Coleoptera: Carabidae). Landsc Ecol 28:487-494 
Josso C, Le Ralec A, Raymond L, Saulais J, Baudry J, Poinsot D, Cortesero AM (2013) Effects of field and landscape variables on crop colonization and biological control of the cabbage root fly Delia radicum. Landsc Ecol 28:1697-1715

Kells AR, Holland JM, Goulson D (2001) The value of uncropped field margins for foraging bumblebees. J Insect Conserv 5:283-291

Kiss J, Kádár F, Kozma E, Tóth I (1993) Importance of various habitats in agricultural landscape related to integrated pest management: a preliminary study. Landsc Urban Plan 27:191-198

Klaus VH, Kleinebecker T, Prati D, Gossner MM, Alt F, Boch S et al (2013) Does organic grassland farming benefit plant and arthropod diversity at the expense of yield and soil fertility? Agric Ecosyst Environ 177:1-9

Koerner W, Dupouey JL, Dambrine E, Benoit M (1997) Influence of past land use on the vegetation and soils of present day forest in the Vosges mountains, France. J Ecol 85:351-358

Kohler F, Verhulst J, KNop E, Herzog F, Kleijn D (2007) Indirect effects of grassland extensification schemes on pollinators in two contrasting European countries. Biol Conserv 135:302-307

Kohler F, Verhulst J, Van Klink R, Kleijn D (2008) At what spatial scale do high-quality habitats enhance the diversity of forbs and pollinators in intensively farmed landscapes? J Appl Ecol 45:753-762

Korpela EL, Hyvönen T, Lindgren S, Kuussaari M (2013) Can pollination services, species diversity and conservation be simultaneously promoted by sown wildflower strips on farmland? Agric Ecosyst Environ 179:18-24

Kosmas C, Danalatos N, Cammeraat LH, Chabart M, Diamantopoulos J, Farand R et al (1997) The effect of land use on runoff and soil erosion rates under Mediterranean conditions. Catena 29:45-59

Kovács-Hostyánszki A, Batáry P, Báldi A (2011) Local and landscape effects on bee communities of Hungarian winter cereal fields. Agric For Entomol 13:59-66

Kovács-Hostyánszki A, Haenke S, Batáry P, Jauker B, Báldi A, Tscharntke T, Holzschuh A (2013) Contrasting effects of massflowering crops on bee pollination of hedge plants at different spatial and temporal scales. Ecol Appl 23:1938-1946

Krause B, Culmsee H (2013) The significance of habitat continuity and current management on the compositional and functional diversity of grasslands in the uplands of Lower Saxony, Germany. FloraMorphology, Distribution, Functional Ecology of Plants 208:299311

Krauss J, Gallenberger I, Steffan-Dewenter I (2011) Decreased functional diversity and biological pest control in conventional compared to organic crop fields. PLoS One 6:e19502

Krewenka KM, Holzschuh A, Tscharntke T, Dormann CF (2011) Landscape elements as potential barriers and corridors for Hymenoptera, wasps and Hymenoptera. Biol Conserv 144:18161825

Kromp B, Steinberger K-H (1992) Grassy field margins and arthropod diversity - a case-study on ground Coleoptera and Araneae in Eastern Austria (Coleoptera, Carabidae, Arachnida, Aranei, Opiliones). Agric Ecosyst Environ 40:71-93

Kruess A (2003) Effects of landscape structure and habitat type on a plant-herbivore-parasitoid community. Ecography 26:283-290

Kruess A, Tscharntke T (1994) Habitat fragmentation, species loss, and biological control. Science (Washington) 264:1581-1584

Kuussaari M, Hyvönen T, Härmä O (2011) Pollinator insects benefit from rotational fallows. Agric Ecosyst Environ 143:28-36

Lagerlof J, Wallin H (1993) The abundance of arthropods along two field margins with different types of vegetation composition - an experimental-study. Agric Ecosyst Environ 4:141-154

Lagerlöf J, Starkb J, Svensson B (1992) Margins of agricultural fields as habitats for pollinating insects. Agric Ecosyst Environ 40:117-124

Langer V (2001) The potential of leys and short rotation coppice hedges as reservoirs for Hymenoptera of cereal aphids in organic agriculture. Agric Ecosyst Environ 87:81-92
Lanzoni A, Masetti A, Plankesteiner D, Burgio G (2003) Role of field margin habitat and annual flowering plant mixture on parasitization of economic agromyzid pests. Landscape Management For Functional Biodiversity, IOBC wprs Bulletin 26:95-100

Lautenbach S, Kugel C, Lausch A, Seppelt R (2011) Analysis of historic changes in regional ecosystem service provisioning using land use data. Ecol Indic 11:676-687

Le Féon V, Schermann-Legionnet A, Delettre Y, Aviron S, Billeter R, Bugter R et al (2010) Intensification of agriculture, landscape composition and wild bee communities: a large scale study in four European countries. Agric Ecosyst Environ 137:143-150

Le Féon V, Burel F, Chifflet R, Henry M, Ricroch A, Vaissière BE, Baudry J (2013) Solitary bee abundance and species richness in dynamic agricultural landscapes. Agric Ecosyst Environ 166:94 101

Lemke A, Poehling HM (2002) Sown weed strips in cereal fields: overwintering site and "source" habitat for Oedothorax apicatus (Blackwall) and Erigone atra (Blackwall)(Araneae: Erigonidae). Agric Ecosyst Environ 90:67-80

Lye G, Park K, Osborne J, Holland J, Goulson D (2009) Assessing the value of rural stewardship schemes for providing foraging resources and nesting habitat for bumblebee queens (Hymenoptera: Apidae). Biol Conserv 142:2023-2032

Maalouly M, Franck P, Bouvier J-C, Toubon J-F, Lavigne C (2013) Codling moth parasitism is affected by semi-natural habitats and agricultural practices at orchard and landscape levels. Agric Ecosyst Environ 169:33-42

MacFadyen S, Gibson R, Raso L, Sint D, Traugott M, Memmott J (2009) Parasitoid control of aphids in organic and conventional farming systems. Agric Ecosyst Environ 133:14-18

MacLeod A (1999) Attraction and retention of Episyrphus balteatus DeGeer (Diptera: Syrphidae) at an arable field margin with rich and poor floral resources. Agric Ecosyst Environ 73:237-244

Mänd M, Mänd R, Williams IH (2002) Bumblebees in the agricultural landscape of Estonia. Agric Ecosyst Environ 89:69-76

Marchi C, Andersen LW, Loeschcke V (2013) Effects of land management strategies on the dispersal pattern of a beneficial arthropod. PLoS One 8:e66208

Menta C, Leoni A, Gardi C, Conti FD (2011) Are grasslands important habitats for soil microarthropod conservation? Biodivers Conserv 20:1073-1087

Meyer B, Jauker F, Steffan-Dewenter I (2009) Contrasting resourcedependent responses of hoverfly richness and density to landscape structure. Basic And Applied Ecology 10:178-186

Miñarro M, Prida E (2013) Hedgerows surrounding organic apple orchards in North-west Spain: potential to conserve beneficial insects. Agric For Entomol 15:382-390

Molinillo M, Lasanta T, García-Ruiz JM (1997) Managing mountainous degraded landscapes after farmland abandonment in the Central Spanish Pyrenees. Environ Manag 21:587-598

Monteiro LB, Lavigne C, Ricci B, Franck P, Toubon J-F, SauphaNor B (2013) Predation of codling moth eggs is affected by pest management practices at orchard and landscape levels. Agric Ecosyst Environ 166:86-93

Moonen AC, Castro-Rodas N, Bàrberi P, Petacchi R (2006) Field margin structure and vegetation composition effects on beneficial insect diversity at farm scale: a case study on an organic farm near Pisa (Italy). Landscape Management for Functional Biodiversity, IOBC wprs Bulletin 29:77-80

Moreno G, Obrador JJ, Garcia A (2007) Impact of evergreen oaks on soil fertility and crop production in intercropped dehesas. Agric Ecosyst Environ 119:270-280

Moreno B, Garcia-Rodriguez S, Canizares R, Castro J, Benitez E (2009) Rainfed olive farming in south-eastern Spain: long-term effect of soil management on biological indicators of soil quality. Agric Ecosyst Environ 131:333-339 
Morlat R, Jacquet A (2003) Grapevine root system and soil characteristics in a vineyard maintained long-term with or without interrow sward. Am J Enol Vitic 54:1-7

Moschini V, Migliorini P, Sacchetti P, Casella G, Vazzana C (2012) Presence of aphid predators in common wheat (Triticum aestivum L.) in organic and conventional agroecosystems of Tuscany. Mediterranean Journal of Economics. Agric Environ 11:58-61

Murray TE, Fitzpatrick U, Byrne A, Fealy R, Brown MJ, Paxton RJ (2012) Local-scale factors structure wild bee communities in protected areas. J Appl Ecol 49:998-1008

Nielsen A, Steffan-Dewenter I, Westphal C, Messinger O, Potts SG, Roberts SP et al (2011) Assessing bee species richness in two Mediterranean communities: importance of habitat type and sampling techniques. Ecol Res 26:969-983

Novara A, Gristina L, SaladiNo SS, Santoro A, Cerda A (2011) Soil erosion assessment on tillage and alternative soil managements in a Sicilian vineyard. Soil Tillage Res 117:140-147

Oberg S (2007) Diversity of Araneae after spring sowing - influence of farming system and habitat type. J Appl Entomol 131:524-531

Öberg S (2009) Influence of landscape structure and farming practice on body condition and fecundity of wolf Araneae. Basic and Applied Ecology 10:614-621

Ockinger E, Smith HG (2007) Semi-natural grasslands as population sources for pollinating insects in agricultural landscapes. J Appl Ecol 44:50-59

Osborne JL, Martin AP, Shortall CR, Todd AD, Goulson D, Knight ME et al (2008) Quantifying and comparing bumblebee nest densities in gardens and countryside habitats. J Appl Ecol 45:784-792

Östman Ö, Ekbom B, Bengtsson J (2001a) Landscape heterogeneity and farming practice influence biological control. Basic and Applied Ecology 2:365-371

Östman Ö, Ekbom B, Bengtsson J, Weibull AC (2001b) Landscape complexity and farming practice influence the condition of polyphagous carabid Coleoptera. Ecol Appl 11:480-488

Paoletti MG (1988) Soil invertebrates in cultivated and uncultivated soils in north eastern Italy. Estratto da redia 71:501-563

Paolettia MG, Boscoloa P, Sommaggioa D (1997) Beneficial insects in fields surrounded by hedgerows in north eastern Italy. Biological Agriculture \& Horticulture 15:310-323

Paredes D, Cayuela L, Campos M (2013) Synergistic effects of ground cover and adjacent vegetation on natural enemies of olive insect pests. Agric Ecosyst Environ 173:72-80

Parmentier L, Meeus I, Cheroutre L, Mommaerts V, Louwye S, Smagghe G (2014) Commercial bumblebee hives to assess an anthropogenic environment for pollinator support: a case study in the region of Ghent (Belgium). Environ Monit Assess 186:2357-2367

Patzold S, Klein C, Brummer GW (2007) Run-off transport of herbicides during natural and simulated rainfall and its reduction by vegetated filter strips. Soil Use Manag 23:294-305

Peregrina, F., Pérez-Álvarez, E. P., Colina, M., García-Escudero, E. (2012) Cover crops and tillage influence soil organic matter and nitrogen availability in a semi-arid vineyard. Archives of Agronomy and Soil Science, 58(sup1), SS95-SS102.

Persson AS, Smith HG (2013) Seasonal persistence of bumblebee populations is affected by landscape context. Agric Ecosyst Environ 165: 201-209

Péter G, Kádár F, Kiss J, Tóth F (2001) Role of field margin in the winter phenophase of carabid Coleoptera (Coleoptera: Carabidae) in winter wheat field. Integrated Control in Cereal Crops, IOBC wprs Bulletin 24:91-94

Pfiffner L, Luka H (2000) Overwintering of arthropods in soils of arable fields and adjacent semi-natural habitats. Agric Ecosyst Environ 78: 215-222

Piekarska-Boniecka H, Siatkowski I, Ratynska H (2010) The influence of agricultural landscape structure on the flora and communities of
Hymenoptera in statistical terms. Polish Journal of Entomology 79:353-365

Plećaš M, Gagić V, Janković M, Petrović-Obradović O, Kavallieratos NG, TomaNović Ž et al (2014) Landscape composition and configuration influence cereal aphid-parasitoid-hyperparasitoid interactions and biological control differentially across years. Agric Ecosyst Environ 183:1-10

Pollard KA, Holland JM (2006) Arthropods within the woody element of hedgerows and their distribution pattern. Agric For Entomol 8:203211

Pommeresche R, Bakken AK, Korsaeth A (2013) Abundance and diversity of Araneae in barley and young leys. The Journal of Arachnology 41:168-175

Pons X, Lumbierres B, Comas J, Madeira F, Starý P (2013) Effects of surrounding landscape on parasitism of alfalfa aphids in an IPM crop system in Northern Catalonia. BioControl 58:733-744

Ponti L, Ricci C, Torricelli R (2003) The ecological role of hedges on population dynamics of Anagrus (Hymenoptera: Mymaridae) in vineyards of Central Italy. Landscape Management for Functional Biodiversity, IOBC wprs Bulletin 26:117-122

Ponti L, Ricci C, Veronesi F, Torricelli R (2005) Natural hedges as an element of functional biodiversity in agroecosystems:the case of a Central Italy vineyard. Bulletin of Insectology 58:19-23

Potts SG, Woodcock BA, Roberts SPM, Tscheulin T, Pilgrim ES, Brown VK, Tallowin JR (2009) Enhancing pollinator biodiversity in intensive grasslands. J Appl Ecol 46:369-379

Pywell RF, James KL, Herbert I, Meek WR, Carvell C, Bell D, Sparks TH (2005) Determinants of overwintering habitat quality for Coleoptera and Araneae on arable farmland. Biol Conserv 123:79_ 90

Rand TA, Tscharntke T (2007) Contrasting effects of natural habitat loss on generalist and specialist aphid natural enemies. Oikos 116:13531362

Rand TA, van Veen FJ, Tscharntke T (2012) Landscape complexity differentially benefits generalized fourth, over specialized third, trophic level natural enemies. Ecography 35:97-104

Raymond L, Sarthou JP, Plantegenest M, Gauffre B, Ladet S, Vialatte A (2014) Immature Diptera overwinter in cultivated fields and may significantly control aphid populations in autumn. Agric Ecosyst Environ 185:99-105

Reyniers M, Maertens K, Vrindts E, De Baerdemaeker J (2006) Yield variability related to landscape properties of a loamy soil in central Belgium. Soil Tillage Res 88:262-273

Ricci B, Franck P, Bouvier JC, Casado D, Lavigne C (2011) Effects of hedgerow characteristics on intra-orchard distribution of larval codling moth. Agric Ecosyst Environ 140:395-400

Riedinger V, Renner M, Rundlöf M, Steffan-Dewenter I, Holzschuh A (2014) Early mass-flowering crops mitigate pollinator dilution in late-flowering crops. Landsc Ecol 29:425-435

Rieux R, Simon S, Defrance H (1999) Role of hedgerows and ground cover management on arthropod populations in pear orchards. Agric Ecosyst Environ 73:119-127

Rundlöf M, Persson AS, Smith HG, Bommarco R (2014) Late-season mass-flowering red clover increases bumble bee queen and male densities. Biol Conserv 172:138-145

Roschewitz I, Hücker M, Tscharntke T, Thies C (2005) The influence of landscape context and farming practices on parasitism of cereal aphids. Agric Ecosyst Environ 108:218-227

Roume A, Deconchat M, Raison L, Balent G, Ouin A (2011) Edge effects on ground Coleoptera at the woodlot-field interface are short-range and asymmetrical. Agric For Entomol 13:395-403

Rundlöf M, Nilsson H, Smith HG (2008) Interacting effects of farming practice and landscape context on bumble bees. Biol Conserv 141: $417-426$ 
Rusch, A, Birkhofer, K, Bommarco, R, Smith, HG, Ekbom, B (2014) Management intensity at field and landscape levels affects the structure of generalist predator communities. Oecologia 1-13

Rusch A, Bommarco R, Jonsson M, Smith HG, Ekbom B (2013) Flow and stability of natural pest control services depend on complexity and crop rotation at the landscape scale. J Appl Ecol 50:345-354

Rusch A, Valantin-Morison M, Roger-Estrade J, Sarthou JP (2012a) Local and landscape determinants of pollen beetle abundance in overwintering habitats. Agric For Entomol 14:37-47

Rusch A, Valantin-Morison M, Roger-Estrade J, Sarthou JP (2012b) Using landscape indicators to predict high pest infestations and successful natural pest control at the regional scale. Landsc Urban Plan 105:62-73

Rusch A, Valantin-Morison M, Sarthou JP, Roger-Estrade J (2011) Multiscale effects of landscape complexity and crop management on pollen beetle parasitism rate. Landsc Ecol 26:473-486

Samnegård U, Persson AS, Smith HG (2011) Gardens benefit bees and enhance pollination in intensively managed farmland. Biol Conserv 144:2602-2606

Samu F, Beleznai O, Tholt G (2013) A potential spider natural enemy against virus vector leafhoppers in agricultural mosaic landscapescorroborating ecological and behavioral evidence. Biol Control 67: 390-396

Sárospataki M, Báldi A, Batáry P, Józan Z, Erdős S, Rédei T (2009) Factors affecting the structure of bee assemblages in extensively and intensively grazed grasslands in Hungary. Community Ecology 10:182-188

Saska P, Vodde M, Heijerman T, Westerman P, van der Werf W (2007) The significance of a grassy field boundary for the spatial distribution of Coleoptera within two cereal fields. Agric Ecosyst Environ 122:427-434

Scheid BE, Thies C, Tscharntke T (2011) Enhancing rape pollen beetle parasitism within sown flower fields along a landscape complexity gradient. Agric For Entomol 13:173-179

Schmidt MH, Tscharntke T (2005a) The role of perennial habitats for central European farmland spiders. Agric Ecosyst Environ 105: 235-242

Schmidt MH, Tscharntke T (2005b) Landscape context of sheetweb spider (Araneae: Linyphiidae) abundance in cereal fields. J Biogeogr $32: 467-473$

Schmidt MH, Roschewitz I, Thies C, Tscharntke T (2005) Differential effects of landscape and management on diversity and density of ground-dwelling farmland spiders. J Appl Ecol 42:281-287

Schneider G, Krauss J, Steffan-Dewenter I (2013) Predation rates on semi-natural grasslands depend on adjacent habitat type. Basic and Applied Ecology 14:614-621

Schroeter L, Irmler U (2013) Organic cultivation reduces barrier effect or arable fields on species diversity. Agric Ecosyst Environ 164:176180

Schüepp C, Herzog F, Entling MH (2014a) Disentangling multiple drivers of pollination in a landscape-scale experiment. Proc R Soc B Biol Sci 281:20132667

Schüepp C, Uzman D, Herzog F, Entling MH (2014b) Habitat isolation affects plant-herbivore-enemy interactions on cherry trees. Biol Control 71:56-64

Schulp CJ, Veldkamp A (2008) Long-term landscape-land use interactions as explaining factor for soil organic matter variability in Dutch agricultural landscapes. Geoderma 146:457-465

Sciarretta A, Trematerra P (2011) Spatio-temporal distribution of Ceratitis capitata population in a heterogeneous landscape in Central Italy. J Appl Entomol 135:241-251

Scohier A, Ouin A, Farruggia A, Dumont B (2013) Is there a benefit of excluding sheep from pastures at flowering peak on flower-visiting insect diversity? J Insect Conserv 17:287-294
Scutareanu P, Lingeman R, Drukker B, Sabelis MW (1999) Crosscorrelation analysis of fluctuations in local populations of pear psyllids and anthocorid bugs. Ecological Entomology 24:354-362

Sheridan H, Finn JA, O'DoNovan G (2009) Botanical rejuvenation of field margins and benefits for invertebrate fauna on a drystock farm in County Longford. Biology and Environment-Proceedings of The Royal Irish Academy 109B(2):95-106

Shvaleva A, Costa e Silva F, Costa JM, Correia A, Anderson M, Lobodo-Vale R et al (2014) Comparison of methane, nitrous oxide fluxes and $\mathrm{CO} 2$ respiration rates from a Mediterranean cork oak ecosystem and improved pasture. Plant Soil 374:883-898

Silva EB, Franco JC, Vasconcelos T, Branco M (2010) Effect of ground cover vegetation on the abundance and diversity of beneficial arthropods in citrus orchards. Bull Entomol Res 100:489-499

Simón N, Montes F, Díaz-Pinés E, Benavides R, Roig S, Rubio A (2013) Spatial distribution of the soil organic carbon pool in a Holm oak dehesa in Spain. Plant Soil 366:537-549

Sjödin NE, Bengtsson J, Ekbom B (2008) The influence of grazing intensity and landscape composition on the diversity and abundance of flower-visiting insects. J Appl Ecol 45:763-772

Skórka P, Lenda M (2010) Abandoned fields as refuges for Lepidoptera in the agricultural landscapes of Eastern Europe. In: Harris EL, Davies NE (eds) Insect habitats: characteristics, diversity and management. Nova Science Publishers, New York, pp 83-103

Smith J, Potts S, Eggleton P (2008) The value of sown grass margins for enhancing soil macrofaunal biodiversity in arable systems. Agric Ecosyst Environ 127:119-125

Smits N, Dupraz C, Dufour L (2012) Unexpected lack of influence of tree rows on the dynamics of wheat aphids and their natural enemies in a temperate agroforestry system. Agrofor Syst 85:153-164

Sonneveld MPW, Van Den Akker JJH (2011) Quantification of C and N stocks in grassland topsoils in a dutch region dominated by livestock farming. J Agric Sci 149:63-71

Starý P, Havelka J (2008) Fauna and associations of aphid parasitoids in an up-dated farmland area (Czech Republic). Bulletin of Insectology 61:251-276

Steckel J, Westphal C, Peters MK, Bellach M, Rothenwoehrer C, Erasmi $S$ et al (2014) Landscape composition and configuration differently affect trap-nesting Hymenoptera, wasps and their antagonists. Biol Conserv 172:56-64

Steffan-Dewenter I, Leschke K (2003) Effects of habitat management on vegetation and above-ground nesting Hymenoptera and wasps of orchard meadows in Central Europe. Biodivers Conserv 12:19531968

Steffan-Dewenter I, Tscharntke T (1999) Effects of habitat isolation on pollinator communities and seed set. Oecologia 121:432-440

Steffan-Dewenter I, Munzenberg U, Burger C, Thies C, Tscharntke T (2002) Scale-dependent effects of landscape context on three pollinator guilds. Ecology 83:1421-1432

Świtoniak M (2014) Use of soil profile truncation to estimate influence of accelerated erosion on soil cover transformation in young morainic landscapes, North-Eastern Poland. Catena 116:173-184

Tatzber M, Stemmer M, Spiegel H, Katzlberger C, Landstetter C, Haberhauer G, Gerzabek MH (2012) 14C-labeled organic amendments: characterization in different particle size fractions and humic acids in a long-term field experiment. Geoderma 177-178:39-48

Thies C, Tscharntke T (1999) Landscape structure and biological control in agroecosystems. Science 285:893-895

Thies C, Haenke S, Scherber C, Bengtsson J, Bommarco R, Clement LW et al (2011) The relationship between agricultural intensification and biological control: experimental tests across Europe. Ecol Appl 21: 2187-2196

Thies C, Roschewitz I, Tscharntke T (2005) The landscape context of cereal aphid-parasitoid interactions. Proc R Soc B Biol Sci 272: 203-210 
Thies C, Steffan-Dewenter I, Tscharntke T (2003) Effects of landscape context on herbivory and parasitism at different spatial scales. Oikos $101: 18-25$

Thies C, Steffan-Dewenter I, Tscharntke T (2008) Interannual landscape changes influence plant-herbivore-parasitoid interactions. Agric Ecosyst Environ 125:266-268

Tkaczuk C, Krzyczkowski T, Wegensteiner R (2012) The occurrence of entomopathogenic fungi in soils from mid-field woodlots and adjacent small-scale arable fields. Acta Mycol 47:191-202

Trichard A, Alignier A, Biju-Duval L, Petit S (2013) The relative effects of local management and landscape context on weed seed predation and carabid functional groups. Basic and Applied Ecology 14:235245

Tscharntke T, Steffan-Dewenter I, Kruess A, Thies C (2002) Contribution of small habitat fragments to conservation of insect communities of grassland-cropland landscapes. Ecol Appl 12:354-363

Tscheulin T, Neokosmidis L, Petanidou T, Settele J (2011) Influence of landscape context on the abundance and diversity of Hymenoptera in Mediterranean olive groves. Bull Entomol Res 101:557-564

Van Geert A, Van Rossum F, Triest L (2010) Do linear landscape elements in farmland act as biological corridors for pollen dispersal? J Ecol 98:178-187

Verboven HA, Uyttenbroeck R, Brys R, Hermy M (2014) Different responses of Hymenoptera and Diptera to land use in an urban-rural gradient show the importance of the nature of the rural land use. Landsc Urban Plan 126:31-41

Veres A, Tóth F, Kiss J, Fetykó K, Orosz S, Lavigne C et al (2012) Spatiotemporal dynamics of Orius spp. (Heteroptera: Anthocoridae) abundance in the agricultural landscape. Agric Ecosyst Environ 162:4551

Vidal S (1997) Factors influencing the population dynamics of Brevicoryne brassicae in undersown brussels sprouts. Entomological Research in Organic Agriculture 15:285-295

Vollhardt IM, Tscharntke T, Wäckers FL, Bianchi FJ, Thies C (2008) Diversity of cereal aphid Hymenoptera in simple and complex landscapes. Agric Ecosyst Environ 126:289-292

Weihrauch F (2008) Overwintering of common green lacewings in hibernation shelters in the Hallertau hop growing area. Bulletin of Insectology 61:67-71

Westphal C, Steffan-Dewenter I, Tscharntke T (2003) Mass flowering crops enhance pollinator densities at a landscape scale. Ecol Lett 6:961-965
Westphal C, Steffan-Dewenter I, Tscharntke T (2009) Mass flowering oilseed rape improves early colony growth but not sexual reproduction of bumble bees. J Appl Ecol 46:187-193

Wiesmeier M, Spörlein P, Geuß U, Hangen E, Haug S, Reischl A et al (2012) Soil organic carbon stocks in southeast Germany (Bavaria) as affected by land use, soil type and sampling depth. Glob Chang Biol 18:2233-2245

Williams A, Hedlund K (2013) Indicators of soil ecosystem services in conventional and organic arable fields along a gradient of landscape heterogeneity in southern Sweden. Appl Soil Ecol 65:1-7

Williams A, Hedlund K (2014) Indicators and trade-offs of ecosystem services in agricultural soils along a landscape heterogeneity gradient. Appl Soil Ecol 77:1-8

Winkler K, Wäckers FL, Termorshuizen AJ, van Lenteren JC (2010) Assessing risks and benefits of floral supplements in conservation biological control. BioControl 55:719-727

Winqvist C, Bengtsson J, Aavik T, Berendse F, Clement LW, Eggers S et al (2011) Mixed effects of organic farming and landscape complexity on farmland biodiversity and biological control potential across Europe. J Appl Ecol 48:570-579

Wissuwa J, Salamon JA, Frank T (2012) Effects of habitat age and plant species on predatory mites (Acari, Mesostigmata) in grassy arable fallows in eastern Austria. Soil Biol Biochem 50:96-107

Woodcock BA, Potts SG, Tscheulin T, Pilgrim E, Ramsey AJ, HarrisonCripps J, Brown VK, Tallowin JR (2009) Responses of invertebrate trophic level, feeding guild and body size to the management of improved grassland field margins. J Appl Ecol 46:920-929

Yang Z, Singh BR, Sitaula BK (2004) Fractions of organic carbon in soils under different crop rotations, cover crops and fertilization practices. Nutr Cycl Agroecosyst 70:161-166

Zádorová T, Žižala D, Penížek V, Čejková Š (2014) Relating extent of colluvial soils to topographic derivatives and soil variables in a Luvisol sub-catchment, Central Bohemia, Czech Republic. Soil and Water Research 9:47-57

Zaller JG, Moser D, Drapela T, Schmöger C, Frank T (2008) Insect pests in winter oilseed rape affected by field and landscape characteristics. Basic and Applied Ecology 9:682-690

Zaller JG, Moser D, Drapela T, Schmöger C, Frank T (2009) Parasitism of stem weevils and pollen beetle in winter oilseed rape is differentially affected by crop management and landscape characteristics. BioControl 54:505-514 